\title{
One-Step Synthesis of Copper and Cupric Oxide Particles from the Liquid Phase by $X$-Ray Radiolysis Using Synchrotron Radiation
}

\author{
Akinobu Yamaguchi, ${ }^{1}$ Ikuo Okada, ${ }^{2}$ Takao Fukuoka, ${ }^{1}$ Mari Ishihara, ${ }^{3}$ \\ Ikuya Sakurai, ${ }^{2}$ and Yuichi Utsumi ${ }^{1}$ \\ ${ }^{1}$ Laboratory of Advance Science and Technology for Industry, University of Hyogo, 3-1-2 Koto, Kamigori, Ako, \\ Hyogo 678-1205, Japan \\ ${ }^{2}$ Synchrotron Radiation Research Center, Nagoya University, Furo-cho, Chikusa-ku, Nagoya, Aichi 464-8603, Japan \\ ${ }^{3}$ Hyogo Prefectural Institute of Technology, 3-1-12, Yukihira, Suma, Kobe 654-0037, Japan \\ Correspondence should be addressed to Akinobu Yamaguchi; yamaguti@lasti.u-hyogo.ac.jp
}

Received 28 September 2016; Accepted 22 November 2016

Academic Editor: Fuxiang Zhang

Copyright (C) 2016 Akinobu Yamaguchi et al. This is an open access article distributed under the Creative Commons Attribution License, which permits unrestricted use, distribution, and reproduction in any medium, provided the original work is properly cited.

The deposition of copper $(\mathrm{Cu})$ and cupric oxide $\left(\mathrm{Cu}_{4} \mathrm{O}_{3}, \mathrm{Cu}_{2} \mathrm{O}\right.$, and $\left.\mathrm{CuO}\right)$ particles in an aqueous copper sulfate $\left(\mathrm{CuSO}_{4}\right)$ solution with additive alcohol such as methanol, ethanol, 2-propanol, and ethylene glycol has been studied by X-ray exposure from synchrotron radiation. An attenuated $\mathrm{X}$-ray radiation time of $5 \mathrm{~min}$ allows for the synthesis of $\mathrm{Cu}, \mathrm{Cu}_{4} \mathrm{O}_{3}, \mathrm{Cu}_{2} \mathrm{O}, \mathrm{and}_{\mathrm{CuO}}$ nano/microscale particles and their aggregation into clusters. The morphology and composition of the synthesized $\mathrm{Cu} / \mathrm{cupric}$ oxide particle clusters were characterized by scanning electron microscopy, scanning transmission electron microscopy, and highresolution transmission electron microscopy with energy dispersive X-ray spectroscopy. Micro-Raman spectroscopy revealed that the clusters comprised cupric oxide core particles covered with $\mathrm{Cu}$ particles. Neither $\mathrm{Cu} / \mathrm{cupric}$ oxide particles nor their clusters were formed without any alcohol additives. The effect of alcohol additives is attributed to the following sequential steps: photochemical reaction due to X-ray irradiation induces nucleation of the particles accompanying redox reaction and forms a cluster or aggregates by LaMer process and DLVO interactions. The procedure offers a novel route to synthesize the $\mathrm{Cu} / \mathrm{cupric}$ oxide particles and aggregates. It also provides a novel additive manufacturing process or lithography of composite materials such as metal, oxide, and resin.

\section{Introduction}

Nanoparticles (NPs), of which sizes are in general below $100 \mathrm{~nm}$, are potentially interesting for applications such as catalysis and optical devices, and the nucleation and fabrication of NPs are fundamental topics of scientific and engineering studies [1-5]. The optical properties of noble metal NPs have attracted considerable attention because these NPs exhibit extremely high absorption and scattering cross sections due to surface plasmon resonance. Metal NPs are currently synthesized by many methods such as sonochemical reaction [6-13], chemical aqueous reduction of metal ions [14-16], microwave-assisted synthesis [17], and UV-visible light or laser-induced photochemical reaction
[18-23]. In these studies, the polyol reaction [24-28] plays a significant important role in NP synthesis. Recently, X-ray irradiation has also been used to generate NPs from liquid solution and tailor NP aggregation at desired locations [2936]. To this end, noble metal NPs are typically used for surface enhanced Raman scattering spectroscopy (SERS) and plasmon-assisted photochemical reactions [1-4, 37]. Potential applications of NPs in a nanoscale material processing have been demonstrated in various fields such as catalysis, medicine, electronics, ceramics, pigments, and cosmetics [1$5]$.

Recently, copper $(\mathrm{Cu})$ and copper oxide-nanostructured materials have attracted considerable attention due to their 
fundamental importance and potential future applications [38-54]. Cupric oxide $\left(\mathrm{Cu}_{2} \mathrm{O}, \mathrm{CuO}\right) \mathrm{NPs}$ are p-type semiconductor materials with a low band-gap energies. Recently, Poizot et al. [40] used cupric oxide NPs as anodes for lithium ion cells. Izaki et al. [47] produced solar cell plates consisting of $\mathrm{Cu}_{2} \mathrm{O}$ and $\mathrm{ZnO}$ NPs. In addition, the cupric oxide NPs have sufficient space to absorb harmful gases. Zhang et al. demonstrated the application of copper oxide NPs as a gas sensor [51]. Thus, copper oxide NPs have additional noteworthy properties, such as nontoxicity, environmental friendliness, high stability, and recyclability. Many reports have provided methods to synthesize and characterize cupric oxide $\left(\mathrm{Cu}_{2} \mathrm{O}\right.$, $\mathrm{CuO}$ ) NPs [38-54]. For example, $\mathrm{CuO}$ NPs were prepared by Brookshier et al. using a spin-coating technique to control $\mathrm{SiO}_{2}$ size [54] and Volanti et al. synthesized CuO flower-like nanostructures using a domestic hydrothermal microwave [38]. Clay and Cohen synthesized $\mathrm{CuO}$ nanoclusters within films of diblock copolymers [52], whereas Lisiecki and Pileni produced $\mathrm{Cu}$ and $\mathrm{CuO}$ NPs from inverse micelle solutions [53].

Radiolysis using synchrotron radiation (SR) has recently been investigated as a radiation-assisted method for the synthesis of NPs [29-36]. Due to the higher brilliance and controllability of X-ray from SR, the X-ray radiolysis has attracted much attention. To date, the synchrotron X-ray synthesis of $\mathrm{Au}, \mathrm{Fe}, \mathrm{Ni}$, and $\mathrm{AuPt}$ alloyed NPs has been reported [29-36]. Thus, the syntheses of various metallic NPs by X-ray irradiation have been investigated. A few studies have reported the synthesis of $\mathrm{Cu}, \mathrm{Cu}_{2} \mathrm{O}, \mathrm{Cu}_{4} \mathrm{O}_{3}$, and $\mathrm{CuO}$ materials using X-ray irradiation from SR. Recently, Oyanagi et al. [55] and Yamaguchi et al. [56] succeeded in producing $\mathrm{Cu}$ particles by exposing diverse copper solutions. Oyanagi et al. [55] used $\mathrm{Cu}(\mathrm{II})$ bis(1,1,1,5,5,5-hexafluoro2,4,pentanedionate) solution with benzopinacol $\mathrm{C}_{26} \mathrm{H}_{22} \mathrm{O}_{2}$, octylamine $\mathrm{C}_{8} \mathrm{H}_{19} \mathrm{~N}$ and diethylene glycol diethyl ether, while Yamaguchi et al. [56] succeeded in producing $\mathrm{Cu}$ NPs by exposing copper sulfate $\left(\mathrm{CuSO}_{4}\right)$ liquid solution mixed with ethanol to X-rays. In the previous study, we simply demonstrated the synthesis of Cu NPs without any detailed analysis. Investigating the formation of $\mathrm{Cu}$ and cupric oxide NPs is required to understand the physical and chemical mechanisms and to develop engineering applications such as lithium ion cells [51], gas sensors [57], and solar cell plates [58].

In this paper, synchrotron X-ray radiation is used to synthesize cupric oxide and $\mathrm{Cu}$ particles from cupric sulfate solutions containing methanol, ethanol, 2-propanol, and ethylene glycol. Here, we investigate additive alcohol type dependence of cupric particles synthesized by X-ray irradiation. High-resolution scanning electron microscope (SEM), scanning transmission electron microscope (STEM), and high-resolution transmission electron microscope (HRTEM) image with energy dispersive X-ray spectroscopy (EDX) are used to obtain a deeper understanding of the formation mechanism. We also employ microscopic Raman spectroscopy to characterize the cupric particles obtained by $\mathrm{X}$-ray irradiation.
TABLE 1: Summary of solutions prepared for X-ray irradiation experiments.

\begin{tabular}{|c|c|c|}
\hline $\begin{array}{l}\text { Prepared solution } \\
(18 \mu \mathrm{L} \text { siphoned off } \\
\text { from the mixed } \\
\text { solution) }\end{array}$ & $\begin{array}{c}\text { Base solution \& } \\
\text { amount }\end{array}$ & $\begin{array}{c}\text { Additive material \& } \\
\text { amount }\end{array}$ \\
\hline Solution \#1 & $\begin{array}{c}10 \% \mathrm{CuSO}_{4} \text { solution } \\
200 \mu \mathrm{L}\end{array}$ & - \\
\hline Solution \#2 & $\begin{array}{c}10 \% \mathrm{CuSO}_{4} \text { solution } \\
200 \mu \mathrm{L}\end{array}$ & $\begin{array}{c}\text { Methanol }\left(\mathrm{CH}_{3} \mathrm{COH}\right) \\
10 \mu \mathrm{L}\end{array}$ \\
\hline Solution \#3 & $\begin{array}{c}10 \% \mathrm{CuSO}_{4} \text { solution } \\
200 \mu \mathrm{L}\end{array}$ & $\begin{array}{c}\text { Ethanol } \\
\left(\mathrm{CH}_{3} \mathrm{CH}_{2} \mathrm{OH}\right) \\
10 \mu \mathrm{L}\end{array}$ \\
\hline Solution \#4 & $\begin{array}{c}10 \% \mathrm{CuSO}_{4} \text { solution } \\
200 \mu \mathrm{L}\end{array}$ & $\begin{array}{c}\text { 2-Propanol } \\
\left(\mathrm{CH}_{3} \mathrm{CH}\left(\mathrm{CH}_{3}\right) \mathrm{OH}\right) \\
10 \mu \mathrm{L}\end{array}$ \\
\hline Solution \#5 & $\begin{array}{c}10 \% \mathrm{CuSO}_{4} \text { solution } \\
500 \mu \mathrm{L}\end{array}$ & $\begin{array}{c}\text { Ethylene glycol } \\
\left(\mathrm{HOCH}_{2} \mathrm{CH}_{2} \mathrm{OH}\right) \\
0.5 \mu \mathrm{L}\end{array}$ \\
\hline
\end{tabular}

\section{Experimental}

The stock solution was prepared by dissolving $18.6 \mathrm{~g}$ of $\mathrm{CuSO}_{4} \cdot 5 \mathrm{H}_{2} \mathrm{O}$ (Wako Chemical, $99.99 \%$ ) in $100 \mathrm{~mL}$ of doubly distilled water. A $100 \mathrm{~mL}$ aliquot of $10 \% \mathrm{CuSO}_{4}$ aqueous solution (solution \#1) was prepared by diluting the stock solution. We siphoned off $200 \mu \mathrm{L} 10 \% \mathrm{CuSO}_{4}$ aqueous solution into a microtube and added $10 \mu \mathrm{L}$ ethanol to obtain the mixed solution (solution \#3). In the similar way, other additives such as methanol (solution \#2) and 2-propanol (solution \#4) were also added into $10 \% \mathrm{CuSO}_{4}$ aqueous solution. In the case of X-ray irradiation experiment with ethylene glycol, the mix ratio of $\mathrm{CuSO}_{4}$ solution and ethylene glycol is $500 \mu \mathrm{L}$ to $0.5 \mu \mathrm{L}$ (solution \#5). We took off $18 \mu \mathrm{L}$ of the mixed solution (including the $\mathrm{CuSO}_{4}$ and ethanol) and added it into the $\mathrm{X}$-ray irradiation system. The prepared solutions for X-ray irradiation experiments are summarized in Table 1.

The particles deposition experiments using the SR were performed on BL8S1 at the Aichi Synchrotron Radiation Center (Aichi SRC). The experimental setup is schematically shown in Figure $1[36,56]$. The X-ray spectra evaluated by the calculation are also shown in the inset of Figure 1(a). As described in the previous work $[36,56]$, a silicon substrate $\left(10 \times 10 \times 0.5 \mathrm{~mm}^{3}\right)$ was dipped into the solution prepared as shown in Table 1 (total amount of $18 \mu \mathrm{L}$ ). The Si substrate dipped in the solution was sealed by a $2 \mu \mathrm{m}$ thick SiN membrane and polytetrafluoroethylene (PTFE) plates as shown in Figure 1(a). The sealed package including $\mathrm{Si}$ substrate dipped in the solution was fixed by the special steel used stainless (SUS) holder as schematically illustrated in Figure 1(a). In addition, a filtered patterned X-ray mask made of SUS was attached on the SUS holder to obtain the contrast by X-ray irradiation. The use of the X-ray mask allows us to easily get more, about tenfold, difference of the photon number in an area directly irradiated by X-ray with respect to the area covered with the X-ray mask, as shown in the spectra of Figure 1(a). The X-ray mask has some hole-arrays with various size through-holes. We chose the hole-array 


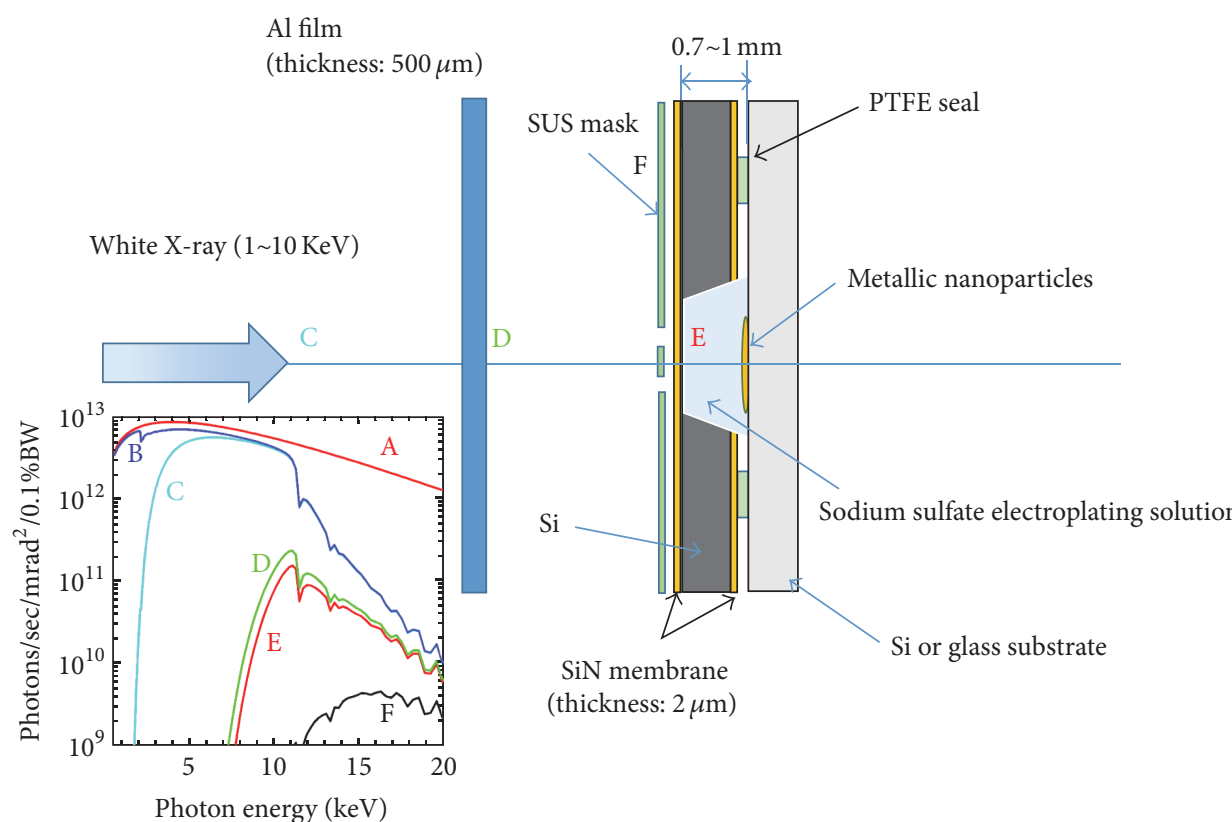

(a)

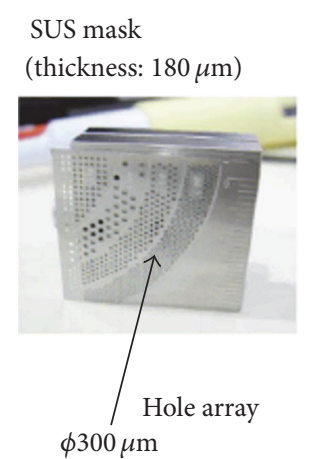

(b)

FIgURE 1: (a) Schematic of experimental setup for the X-ray irradiation of liquid solution. The inset shows X-ray spectra. The evaluated photon intensity obtained from (A): synchrotron radiation at BL8S1 of Aichi SRC, (B): Pt mirror (incident angle: $0.2^{\circ}$ ), (C): $400 \mu \mathrm{m}$ thick Be film, (D): $500 \mu \mathrm{m}$ thick Al film, (E): metallic solution through air (1 m distance), and (F): $180 \mu \mathrm{m}$ thick steel used stainless (SUS) mask. (b) Photograph of specimen with the SUS mask.

consisting of through-hole with diameter of $300 \mu \mathrm{m}$. The specimen prepared for the X-ray irradiation was placed on the irradiation system. After exposure to synchrotron X-rays, we washed the specimen using deionization water to remove residual dross except particles. The particles synthesized onto the silicon substrate were observed by field emission scanning electron microscopy (FE-SEM; JEOL JSM-7001F) with EDX to perform the element analysis. To prepare the cross-sectional sample for transmission electron microscope (TEM) observation, we fixed the sample on TEM observation grid consisting of $\mathrm{Al}$ and Mo using a resin. A focused ion beam (FIB) was used to expose the cross-sectional surface of the sample to observe the TEM image. We obtained the cross-sectional images and elemental maps of the synthesized particles using TEM (JEOL JEM-2100F) with EDX (JEOL, JED-2300T \& Gatan, GIF Quantum ER). Micro-Raman measurements (JASCO, NRS-5100) were performed using the $532 \mathrm{~nm}$ wavelength as the excitation source. The power was maintained at $3.2 \mathrm{~mW}$, and a field lens with a magnification of $100 \mathrm{x}$ was used. The diameter of the laser spot is about $1 \mu \mathrm{m}$. All experiments were performed at room temperature and in the atmosphere.

\section{Results and Discussion}

When the silicon substrate with only $\mathrm{CuSO}_{4}$ solution with no additives (solution \#1) was exposed to $\mathrm{X}$-rays, no particles were synthesized; particles and clusters were only generated in the presence of ethanol (solution \#3). Figure 2 shows the SEM image after a $10 \% \mathrm{CuSO}_{4}$ containing ethanol (solution
\#3) was irradiated with X-rays for $5 \mathrm{~min}$. Here, the X-ray was attenuated by $500 \mu \mathrm{m}$ thick $\mathrm{Al}$ foil as shown in Figure 1 $[36,56]$. As shown in Figure 2(a), a slit pattern is well defined. When magnified, the slit patterns were found to contain particles. The magnified SEM images of small particles and aggregates are represented in Figures 2(b)-2(d), showing that they are not detached from the Si substrate even after washing because of strong van der Waals interaction.

To confirm the composition of the synthesized particles, elementary analysis was carried out by EDX. The inset of the magnified SEM image in Figure 3(a) represents that the positions at which EDX are measured. The red squares correspond to the areas measured by EDX. Signals of elements $\mathrm{C}, \mathrm{Cu}$, and $\mathrm{Si}$ are observed in the spectra in Figures 3(a) and $3(c)$, while an enlarged signal of $\mathrm{O}$ is seen in Figure 3(b). The $\mathrm{Cu} / \mathrm{O}$ ratios in Figures $3(\mathrm{a})-3(\mathrm{c})$ are roughly estimated to be about $9 / 0.5,7 / 2$, and $9 / 0.5$, respectively. Here, the EDX peak of $\mathrm{Si}$ is derived from the silicon substrate because the synthesized particles are small enough to pick up the $\mathrm{Si}$ elementary information as the background signal. As a result, these spectra suggest that the core particle is different from the additional particles which attach on it. Carbon $(C)$ is in the all particles, while sulfur $(\mathrm{S})$ is not included in them. C is considered to be derived from contamination or the additive ethanol. C from ethanol is expected to play an important role in the nucleation process, in which the added ethanol facilitates the redox reaction and nucleates the $\mathrm{Cu}$ and cupric oxide particles [38].

To investigate the morphology and composition, STEM was performed and elemental maps were collected using 


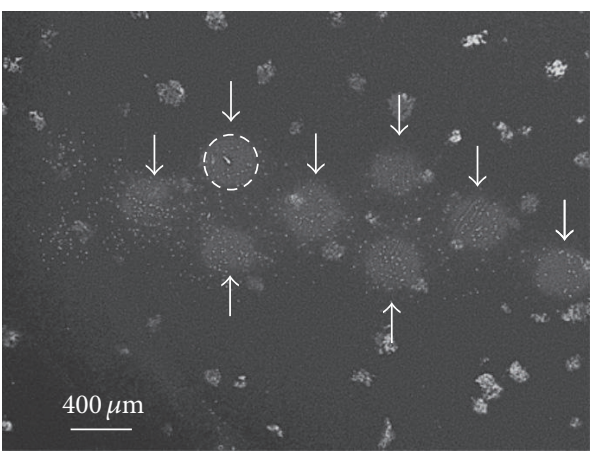

(a)

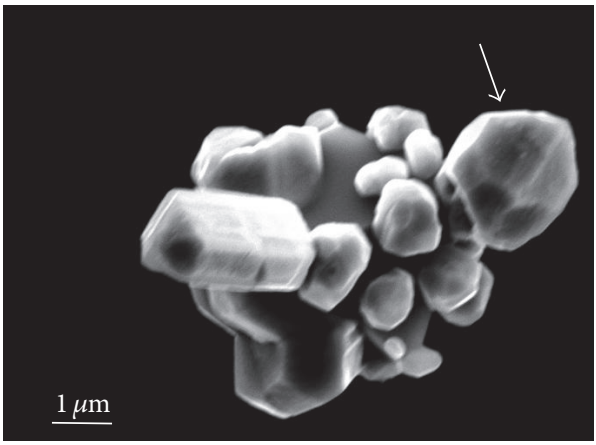

(c)

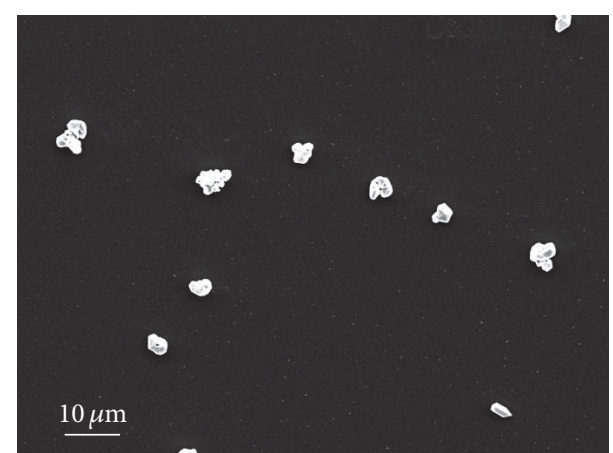

(b)

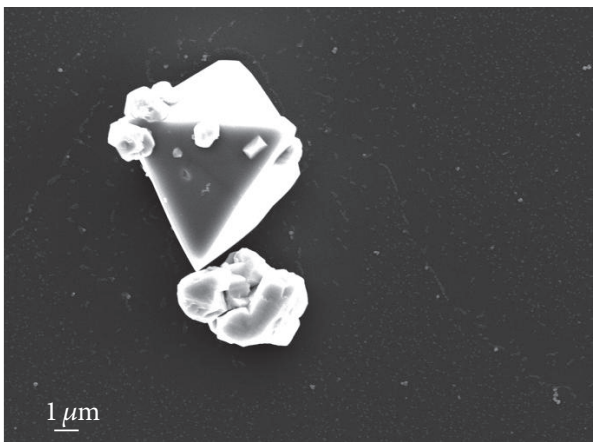

(d)

FIGURE 2: (a) SEM image of a well-patterned $\mathrm{CuSO}_{4}$ solution with ethanol (solution \#3) after X-ray irradiation for 5 min. The dashed circle and arrows correspond to the slit patterned areas. (b) Magnified SEM image of Cu particles nucleated from the mixed solution under X-ray irradiation. ((c) and (d)) High-resolution SEM images of the nucleated particles. The arrow in (c) points out a cuboctahedral like particle.
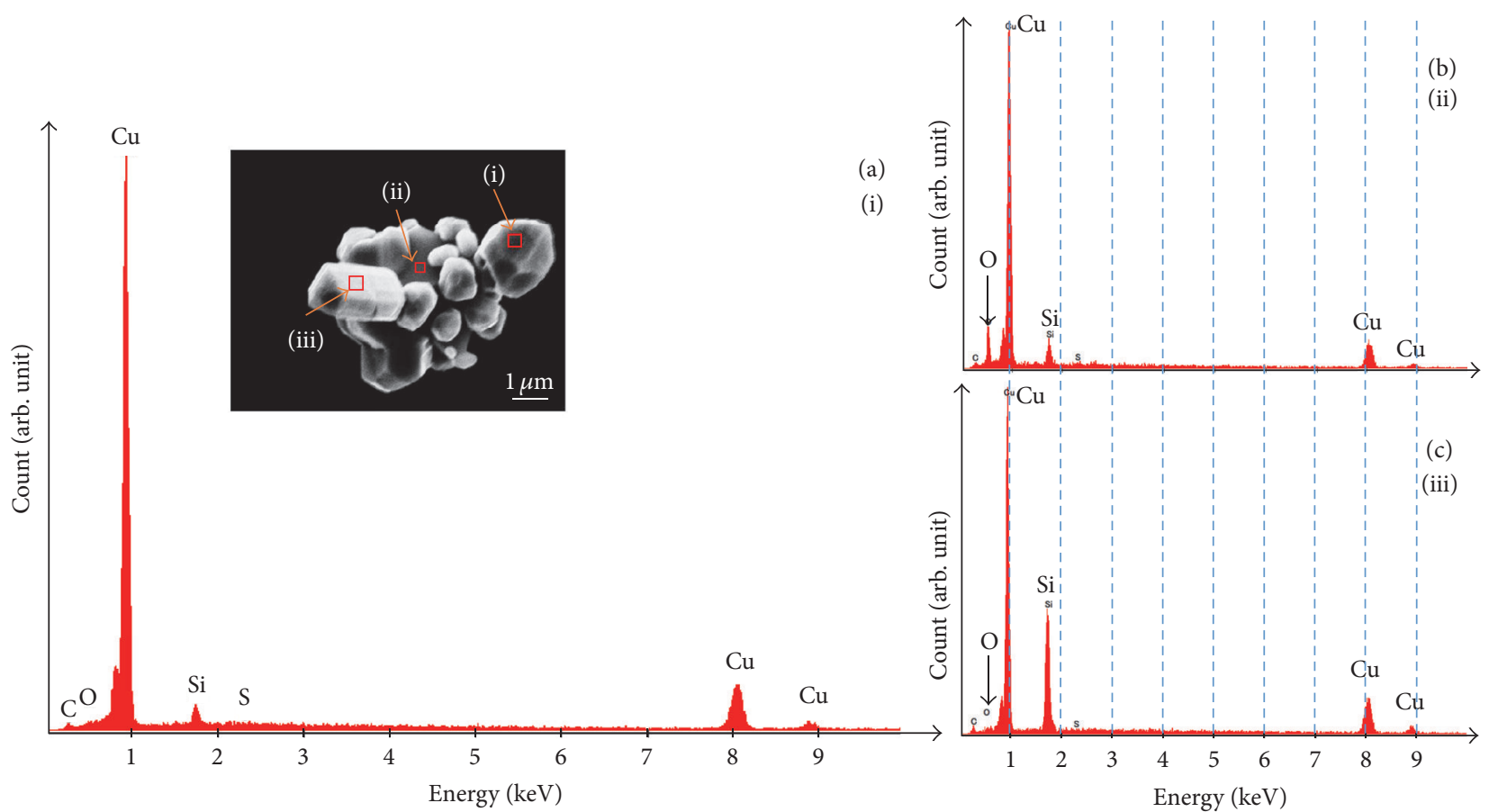

FIGURE 3: In the inset of (a), three red squared frames (i), (ii), and (iii) on the high-resolution SEM image of the particle depict the EDX measurement positions. EDX spectra measured from the positions (i), (ii), and (iii) are shown in (a), (b), and (c), respectively. The position (ii) corresponds to the surface of the core particle, while the positions (i) and (iii) are the surfaces of attached particles. 


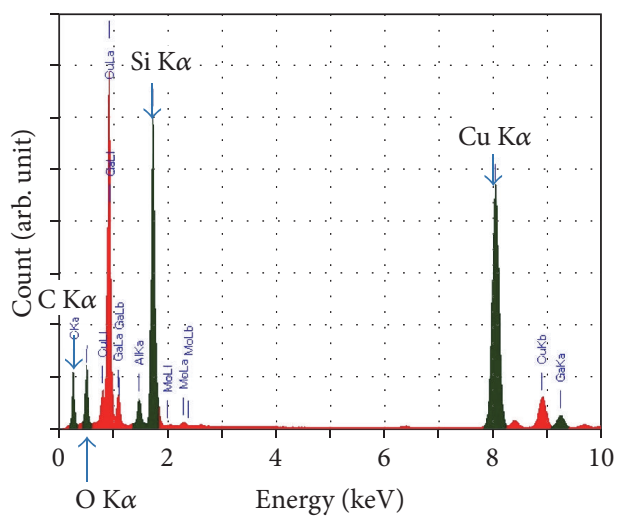

(a)

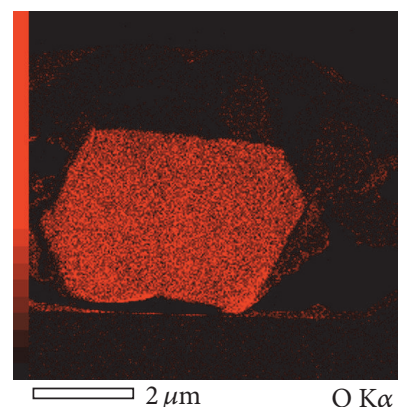

(d)

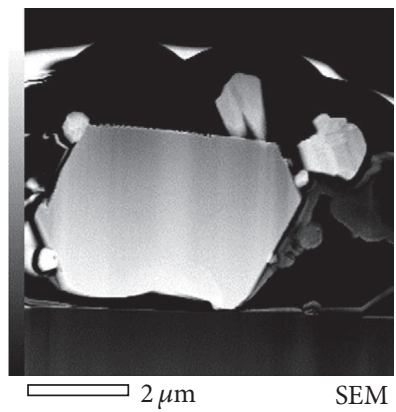

(b)

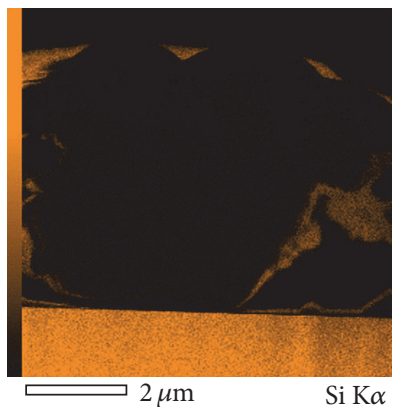

(e)

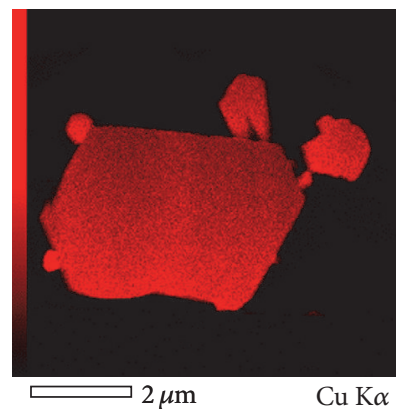

(c)

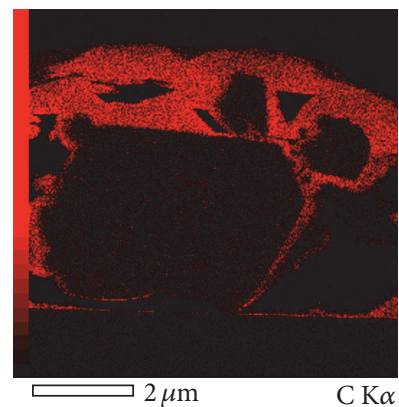

(f)

FIGURE 4: (a) EDX spectrum of the observed cross-sectional area shown in secondary-electron topographical TEM image of (b). (c)-(f) Elemental mappings of $\mathrm{Cu}, \mathrm{O}, \mathrm{Si}$, and $\mathrm{C}$, respectively.

EDX. Figure 4(a) shows the EDX spectrum of the crosssectional area of a cluster generated by X-ray irradiation in the liquid solution shown in Figure 4(b), which is the STEM image. The spectra includes necessary elemental information along with nonessential signals derived from the TEM grid mount materials ( $\mathrm{C}, \mathrm{Al}, \mathrm{Si}$, and $\mathrm{Mo}$ ) and a $\mathrm{Ga}$ signal from the focused ion beam (FIB) milling process. In this manuscript, except the carbon $\mathrm{C}$, elementary maps of $\mathrm{Al}, \mathrm{Mo}$, and $\mathrm{Ga}$ are not shown to avoid cumbersome maps of which provide nonessential phenomena. Figures 4(c)-4(f) show the elementary maps of $\mathrm{Cu}, \mathrm{O}, \mathrm{Si}$, and $\mathrm{C}$, respectively; the bright and dark contrasts correspond to high and low elemental abundance, respectively. Note that the elements $\mathrm{Si}$ and $\mathrm{C}$ remained from the polishing agent slurry and mold resin, respectively, after FIB milling. Thus, both elements reside around the particles near the TEM grid frame, as shown in Figures 4(e) and 4(f). This cross-sectional TEM elementary mapping indicates that all synthesized particles are at least including $\mathrm{Cu}$ as shown in Figure 4(c) and the element $\mathrm{C}$ does not play an important role in the ripping process of the particles. By comparison with Figures $4(\mathrm{c})$ and $4(\mathrm{~d})$, the amount of oxygen $(\mathrm{O})$ is higher included in the core particle, while oxygen distribution is barely visible in the small particles attached on the core particle (Figure 4(d)). One can see the single crystalline-like structure in all synthesized particles, because we recognized the several facets in morphology observation using TEM and SEM.

To understand the details of the elementary distributions in the synthesized particles, the magnified STEM images and EDX mappings are shown in Figure 5. Figure 5(a) shows the topographical STEM image of the cross section of the aggregate. Figures 5(b) and 5(c) show the EDX elementary mappings of $\mathrm{Cu}$ (red-colored) and $\mathrm{O}$ (orangecolored), respectively. The elemental mappings clearly show anisotropic distributions of $\mathrm{Cu}$ and $\mathrm{O} . \mathrm{O}$ is almost detected in the original single crystalline core region, whereas $\mathrm{Cu}$ is mainly found in all particles, similarly to the results shown in Figures 4 and 5.

Furthermore, we collected the micro-Raman spectra in order to reveal crystallographic information. The photograph insets of Figure 6 show the respective aggregates consisting some particles. The labels (A), (C), and (D) correspond to the measurement positions of micro-Raman spectroscopies. The bright green positions correspond to the areas irradiated by the excitation laser. Figures $6(a)-6(d)$ show the microRaman spectra of (a) surface of metallic particle, (b) silicon substrate, (c) surface of core particle, and (d) particle on the core particle, respectively. The micro-Raman spectrometer is so sensitive that it can pick up the information at focal depth of about $500 \mathrm{~nm}$. As shown in Figures 6(a) and 6(d), the broad 


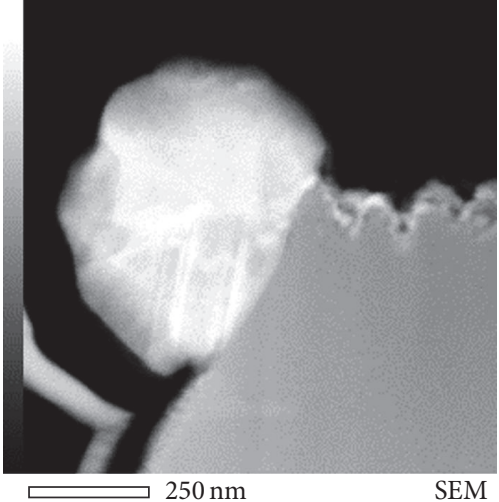

(a)

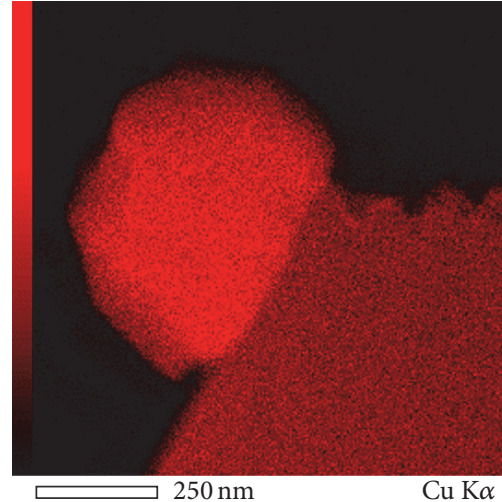

(b)

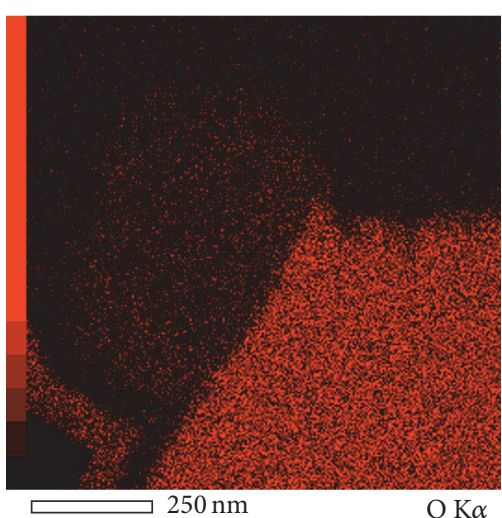

(c)

FIGURE 5: (a) High-resolution TEM topographical image of the aggregate cross section. ((b) and (c)) Elementary mappings of Cu and O, respectively.

spectra are observed, indicating that the particles attaching on core particle are metal and are deduced that the nucleation, growth, or aggregate of $\mathrm{Cu}$ particles occurred.

Next, we focus on the spectrum of Figure 6(c). The peaks at $277,324,520$, and $613 \mathrm{~cm}^{-1}$ appeared clearly in Figure 6(c). These peaks are possibly attributed to summation of three cupric oxides: $\mathrm{Cu}_{2} \mathrm{O}, \mathrm{CuO}$, and $\mathrm{Cu}_{4} \mathrm{O}_{3}[38,39]$. Although a comparison of Raman spectra shown in Figures 6(a), 6(c), and 6(d) with that of the Si substrate in Figure 6(b) indicates that the peak at $520 \mathrm{~cm}^{-1}$ is attributed to the Si substrate, there remains the undeniable possibility that the peak at $520 \mathrm{~cm}^{-1}$ is derived from $\mathrm{A}_{1 \mathrm{~g}}$ mode of $\mathrm{Cu}_{4} \mathrm{O}_{3}$ because the particle volume is thick enough to shade the excitation laser reaching Si substrate. Accordingly to the previous studies of Debbichi et al. [39] and Volanti et al. [38], our observed Raman signals at 277,324, and $613 \mathrm{~cm}^{-1}$ from the core particle correspond to Raman signals from $\mathrm{Ag}\left(283.8 \mathrm{~cm}^{-1}\right)$ and $\mathrm{Bg}$ (333.5 and $622.5 \mathrm{~cm}^{-1}$ ) modes of $\mathrm{CuO}$, respectively [38, 39]. In this study, the corresponding Raman shifts are a little bit lower than those reported in [40,41]. As shown in the inset photograph of Figure 6(d) after the measurement of Raman spectra, the particles that the laser had been focused on were slightly melted. It is attributed that a red shift was induced by the heating effect from laser excitation. In addition, we understand the potential of the broad Raman peak structure ranging from 500 to $630 \mathrm{~cm}^{-1}$ being originated from $\mathrm{Cu}_{2} \mathrm{O}$ $[38,39]$. The result may be explainable for $\mathrm{Cu} / \mathrm{O}$ (at \%) ratios of the aggregates by comparing with EDX measurements; however, in the present stage, it allows us to deduce that the synthesized particle is expected to be a composited cupric oxide consisting of $\mathrm{CuO}, \mathrm{Cu}_{2} \mathrm{O}$, and $\mathrm{Cu}_{4} \mathrm{O}_{3}$, while some particles attached to the core particle were deduced to be $\mathrm{Cu}$ particles. Thus, in either case, we demonstrated one-step synthesis of $\mathrm{Cu} /$ cupric oxide and the aggregates induced from the liquid solution by direct X-ray irradiation.

Various investigations were performed to understand the mechanism of particle formation based on the interaction of sonochemical preparation [6-13], laser light [1823], microwave irradiation [14-17, 38, 39, 41-51], and X-ray and $\gamma$-ray irradiation (radiolysis) $[29-36,55,56]$. For photochemical reactions, both thermal and electronic excitation effects were considered and discussed. To our knowledge, no report has discussed the particle formation mechanism from $\mathrm{CuSO}_{4}$ solution under X-ray irradiation. Therefore, we have attempted to understand the phenomenological chemical reaction process.

In our experiment, hydrated electrons, hydroxyl radicals, and hydrogen atoms were the reactive intermediates in the $\mathrm{X}$ ray irradiation of the mixed aqueous solution. As described in previous studies, the X-ray irradiation from SR provides the proton radical and hydroxyl radical as the following [59-65]:

$$
\mathrm{H}_{2} \mathrm{O} \stackrel{\text { X-ray }}{\longrightarrow} \mathrm{e}_{\mathrm{aq}}^{-}, \cdot \mathrm{H}^{\circ} \mathrm{OH}, \mathrm{H}_{2} \mathrm{O}_{2}, \mathrm{H}_{2}
$$

As described above, in this study, the X-ray irradiation of only $\mathrm{CuSO}_{4}$ solution (without ethanol) did not result in the formation of any particles. This is because the proton and hydroxyl radicals provided by X-ray irradiation are not sufficient to form copper particles via reduction due to the hydration.

Upon the addition of an alcohol (e.g., methanol and ethanol), the ${ }^{\circ} \mathrm{OH}$ and ${ }^{\circ} \mathrm{H}$ radicals are scavenged to yield reducing organic radicals. In the case where ethanol is added to the solution, proton and hydroxyl radicals react as follows [59-65]:

$$
\begin{gathered}
\cdot \mathrm{OH}\left({ }^{\circ} \mathrm{H}\right)+\mathrm{CH}_{3} \mathrm{CH}_{2} \mathrm{OH} \longrightarrow \mathrm{H}_{2} \mathrm{O}\left(\mathrm{H}_{2}\right)+{ }^{\cdot} \mathrm{CH}_{2} \mathrm{OH} \\
\mathrm{CH}_{3} \mathrm{CH}_{2} \mathrm{OH} \stackrel{\text { X-ray }}{\longrightarrow} \mathrm{CH}_{3} \mathrm{CHO}+2 \mathrm{e}^{-}+2 \mathrm{H}^{+} \\
\left(\mathrm{CH}_{3} \mathrm{CH}_{2} \mathrm{OH}\right)_{n} \stackrel{\text { X-ray }}{\longrightarrow}\left[\left(\mathrm{CH}_{3} \mathrm{CH}_{2} \mathrm{OH}\right)_{n}^{+}\right]^{*}+\mathrm{e}^{-} \\
\left(\mathrm{CH}_{3} \mathrm{CH}_{2} \mathrm{OH}\right)_{n} \stackrel{\text { X-ray }}{\longrightarrow} \\
\left(\mathrm{CH}_{3} \mathrm{CH}_{2} \mathrm{OH}\right)_{n-1} \mathrm{H}^{+}+\mathrm{CH}_{3} \mathrm{CHO}+\mathrm{e}^{-}
\end{gathered}
$$




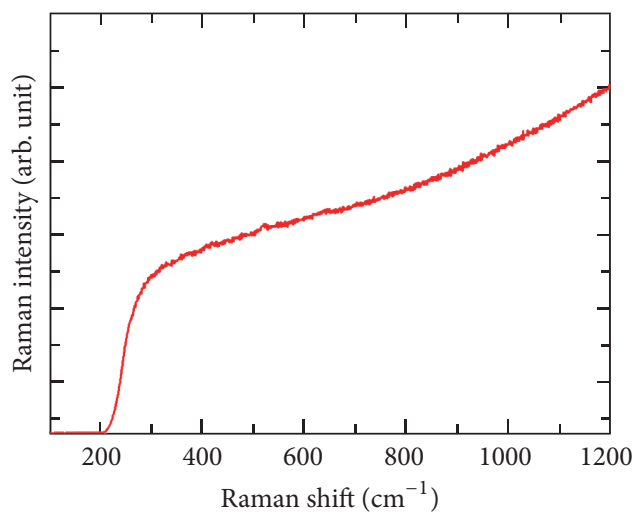

(a)

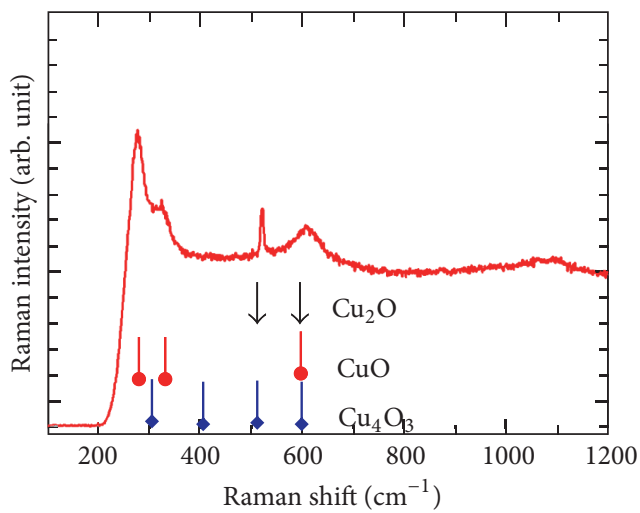

(c)

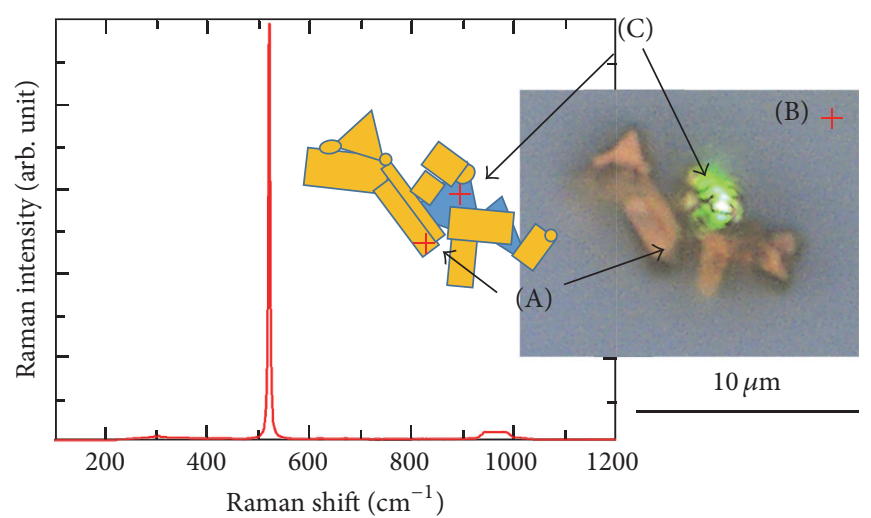

(b)

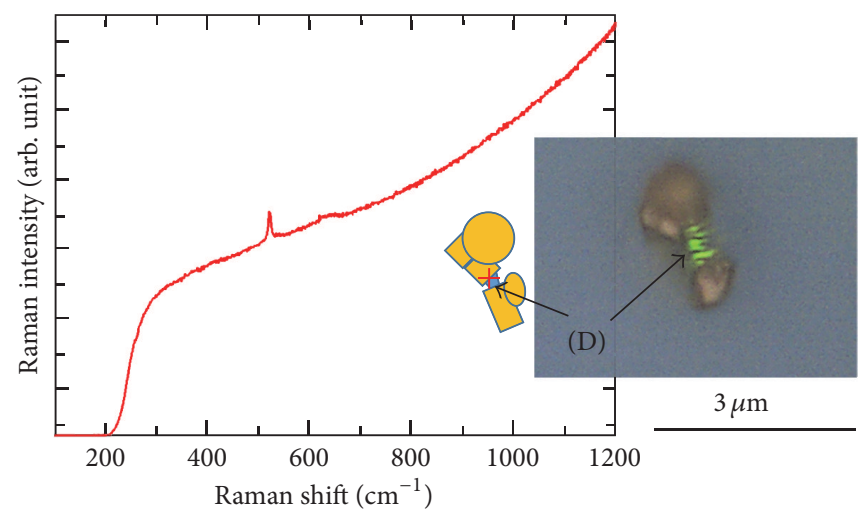

(d)

FIGURE 6: (a) Micro-Raman spectrum of the particle attached on the core particle. The optical image of a typical aggregate is shown in the inset of (b). The green portion of the inset photograph shown in (B) shows the position irradiated by the green laser (wavelength $=532 \mathrm{~nm}$ ). Micro-Raman spectra of (b) the Si substrate, (c) core and particle attached on the core particle, and (d) other particles, respectively. Indexes were taken from the following Raman spectrum patterns: $\mathrm{Cu}_{2} \mathrm{O}, \mathrm{CuO}$, and $\mathrm{Cu}_{4} \mathrm{O}_{3}[38,39]$.

The several candidates of associated reactions are taking place in the mixed solution under the X-ray irradiation, as follows $[58,63-65]$ :

$$
\begin{gathered}
\mathrm{Cu}^{2+}+2 \mathrm{e}^{-} \longrightarrow \mathrm{Cu}^{0} \\
\mathrm{Cu}^{2+}+2 \mathrm{CH}_{3} \mathrm{CHO}+2\left(\mathrm{OH}^{-}\right) \longrightarrow \\
\mathrm{Cu}^{0}+2 \mathrm{CH}_{3} \mathrm{COOH}+\mathrm{H}_{2} \\
\mathrm{Cu}^{2+}+2\left(\mathrm{OH}^{-}\right) \longrightarrow \mathrm{Cu}(\mathrm{OH})_{2} \\
\mathrm{Cu}(\mathrm{OH})_{2} \longrightarrow \mathrm{CuO}+\mathrm{H}_{2} \mathrm{O} \\
\mathrm{Cu}(\mathrm{OH})_{2}+\mathrm{Cu} \longrightarrow \mathrm{Cu}_{2} \mathrm{O}+\mathrm{H}_{2} \mathrm{O} \\
2 \mathrm{CuO}+\mathrm{Cu}_{2} \mathrm{O} \longrightarrow \mathrm{Cu}_{4} \mathrm{O}_{3}
\end{gathered}
$$

Here, the $\mathrm{CuO}, \mathrm{Cu}_{2} \mathrm{O}, \mathrm{Cu}_{4} \mathrm{O}_{3}$, and $\mathrm{Cu}$ particles are finally reduced and deposited onto the silicon substrate and $\mathrm{SiN}$ membrane.

Here, we can obtain cubic, cuboctahedral, and octahedral particles as shown in Figure 2. The nucleation and growth process can be basically explained by LaMer model [66] and the aggregation mechanism derived from the Derjaguin,
Landau, Verwey, and Overbeek (DLVO) model [67, 68]. In addition, for the silicon substrate, the $\mathrm{H}$-terminated $\mathrm{Si}$ substrate produced during the X-ray irradiation may play an important role in particle synthesis, as described in [46].

To investigate the functional group dependence of particle synthesis initiated by $\mathrm{X}$-ray radiolysis, we added methanol, 2-propanol, or ethylene glycol to $10 \% \mathrm{CuSO}_{4}$ solution. The concentration of the additives of methanol and 2-propanol was the same as the case of X-ray irradiation with ethanol. The mixture ratio of the $10 \% \mathrm{CuSO}_{4}$ solution and ethylene glycol was $500 \mu \mathrm{L}$ to $0.5 \mu \mathrm{L}$ (solution \#5), while the ratio of the others (methanol, ethanol, and 2-propanol) was $200 \mu \mathrm{L}$ to $10 \mu \mathrm{L}$. As a result, the synthesis of particles is confirmed. The SEM images and EDX spectra and micro-Raman spectra of morphologies of particles and surface of Si substrate after X-ray irradiation of $\mathrm{CuSO}_{4}$ solution with methanol, 2propanol, and ethylene glycol are shown in Figures 7-9, 10-12, and $13-15$, respectively. We found that the single crystalline like particles and their aggregates are also formed in the cases of additive methanol, 2-propanol, and ethylene glycol, respectively. In addition, the dappling surfaces, where the bright and dark contrasts are randomly distributed in Figures 10 and 13, on irradiated area appear in the both cases of X-ray 


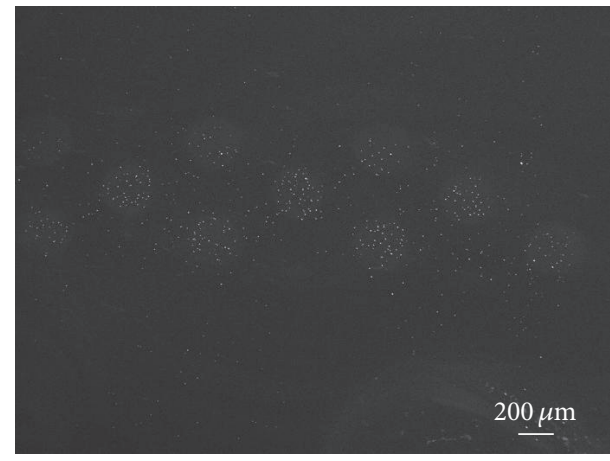

(a)

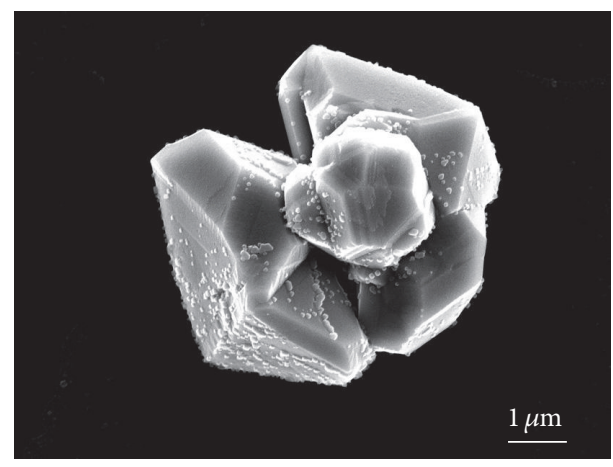

(c)

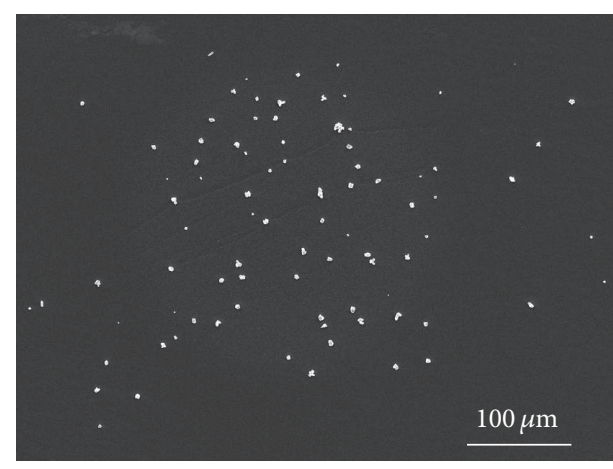

(b)

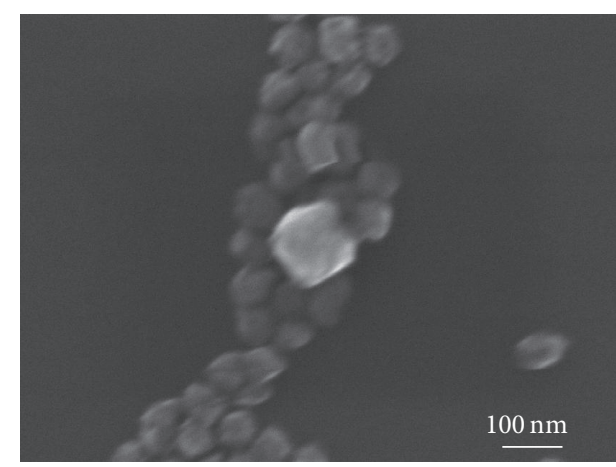

(d)

Figure 7: (a) SEM image of a well-patterned $\mathrm{CuSO}_{4}$ solution with added methanol (solution \#2) after X-ray irradiation for 5 min. (b) Magnified SEM image of Cu NPs nucleated from the mixed solution under X-ray irradiation. ((c) and (d)) High-resolution SEM images of the synthesized particles.

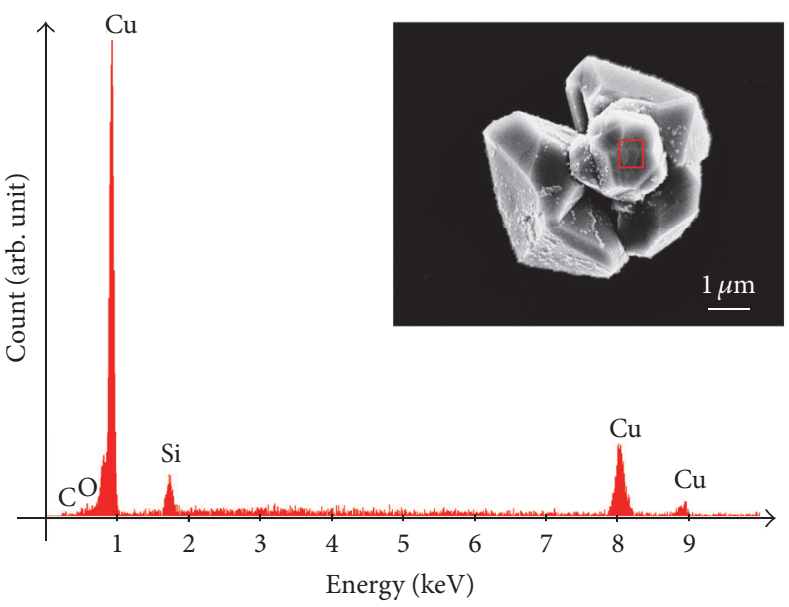

(a)

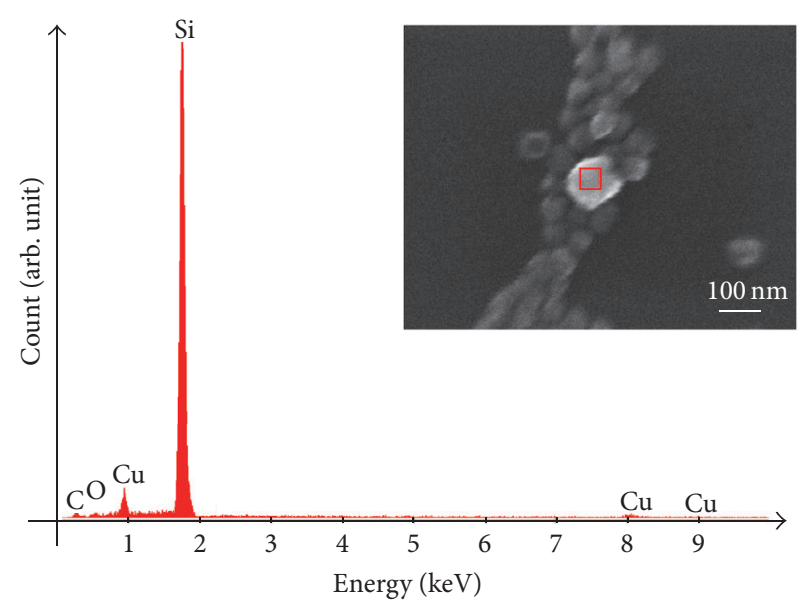

(b)

FIGURE 8: EDX spectra of the red squared areas (a) and (b) in the synthesized particles observed in Figures 7(c) and 7(d), respectively.

irradiation under the application of 2-propanol and ethylene glycol. According to the EDX analysis (not shown here), the dappled shade area is consisting of $\mathrm{Si}$. This result indicates that dips are formed in the dappled shade area by etching process of $\mathrm{Si}$ due to $\mathrm{X}$-ray radiolysis with 2-propanol and ethylene glycol.
To confirm the composition of the synthesized cupric particles with methanol and 2-propanol, we analyzed the synthesized particles or clusters by EDX spectroscopy, as shown in Figures 8 and 11, respectively. By comparison with these spectra, the EDX spectra indicate that the synthesized particles consisted mostly of $\mathrm{Cu}$. Next, the micro-Raman 


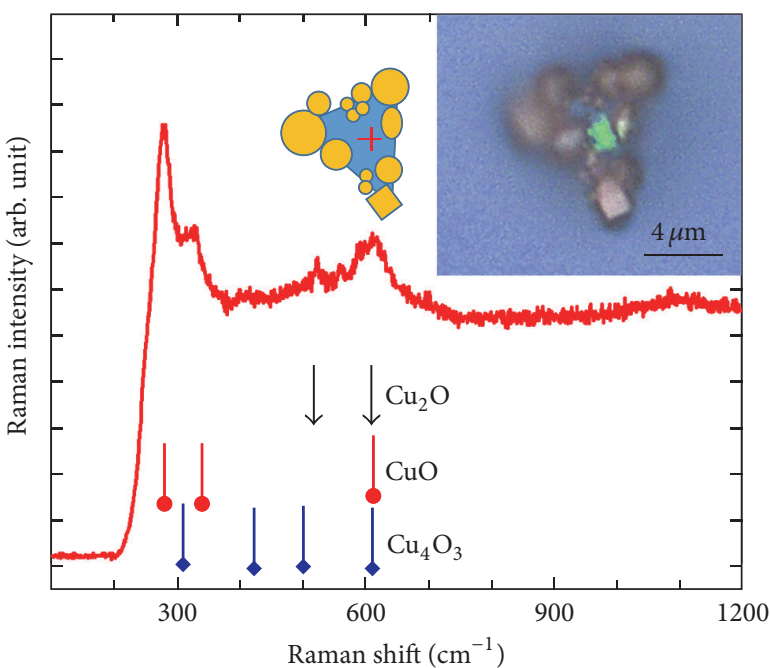

(a)

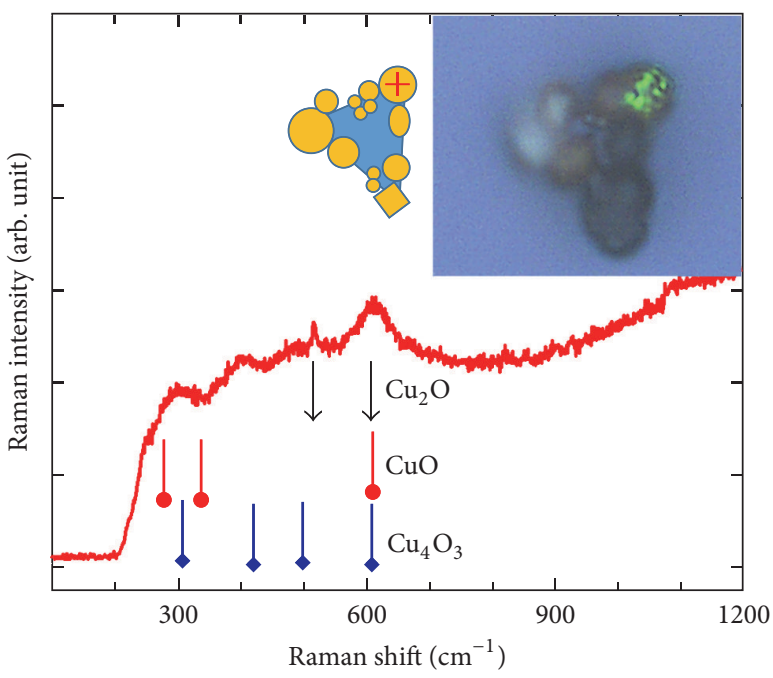

(c)

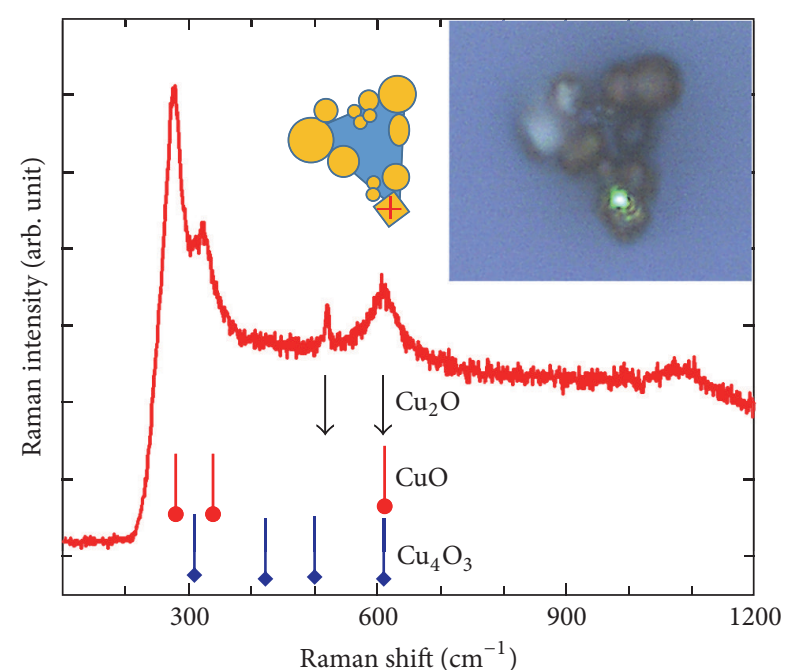

(b)

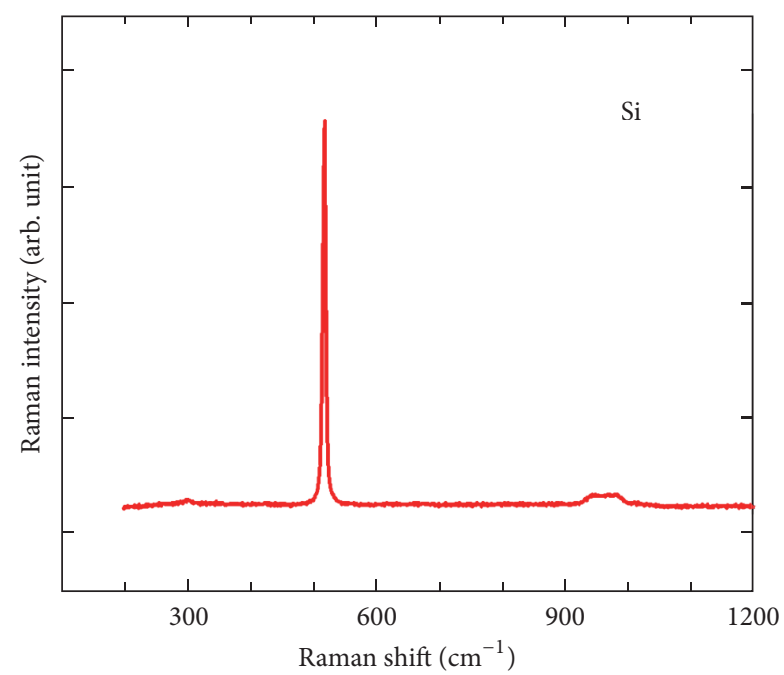

(d)

FIGURE 9: Micro-Raman spectra of the measurement positions (a), (b), and (c) on the particle aggregate synthesized from $\mathrm{CuSO}_{4}$ solution mixed with 2-propanol (solution \#4) and Si substrate. The inset photographs display the green laser position on the measurement area. Indexes were taken from the following Raman spectrum patterns: $\mathrm{Cu}_{2} \mathrm{O}, \mathrm{CuO}$, and $\mathrm{Cu}_{4} \mathrm{O}_{3}[38,39]$.

spectra of the aggregate of these particles are shown in Figures 9 and 12. Comparing the spectrum in Figure 9(c) with that in Figure 12, we found the two spectra are almost the same and are educed to be derived from $\mathrm{Cu}_{4} \mathrm{O}_{3}$. The spectra shown in Figures 9(a) and 9(b) are similar with Figure 6(c) of the case of particles synthesized from $\mathrm{CuSO}_{4}$ solution with additive ethanol (solution \#2). These results indicate that the composition of the particles is almost the same and is expected to be consisting of $\mathrm{CuO}$ and $\mathrm{Cu}_{2} \mathrm{O}$. The particles attached on the core particles are expected to be $\mathrm{Cu}$ particles.

Next, we analyzed urchin-like NPs synthesized by Xray radiolysis with ethylene glycol (solution \#5) by EDX spectroscopy. Figure 14 indicates that both the outshoot and core consisted of cupric oxide. The outshoot seems to contain a higher proportion of carbon $\mathrm{C}$ than the core. The microRaman spectra of these particles synthesized from solution with ethylene glycol (solution \#5) are shown in Figure 15. Unfortunately, the particles were burned after the microRaman spectroscopy was measured as shown in the inset of Figure 15. Comparing the spectrum in Figure 15 with the other spectra depicted in Figures 6, 9, and 12, we found that the obtained spectrum is expected to be derived from the composite consisting of $\mathrm{CuO}$ and $\mathrm{Cu}_{2} \mathrm{O}$.

We investigate the dependence of the deposited particle size on the kinds of additive alcohol. Here, to simplify the estimation of particle size, we evaluated the maximum length of the synthesized particles because their shapes were various and diversified. The probability densities of the particles 


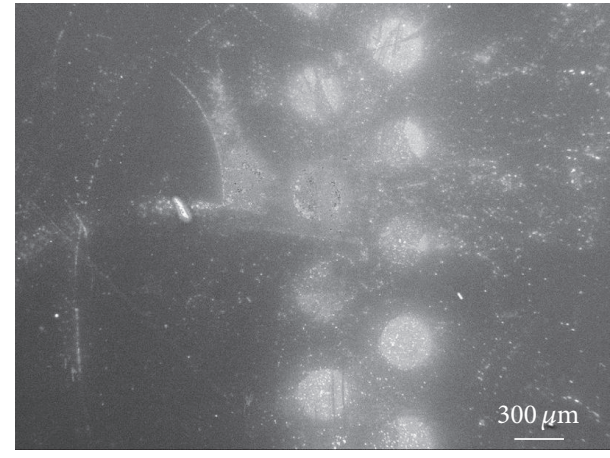

(a)

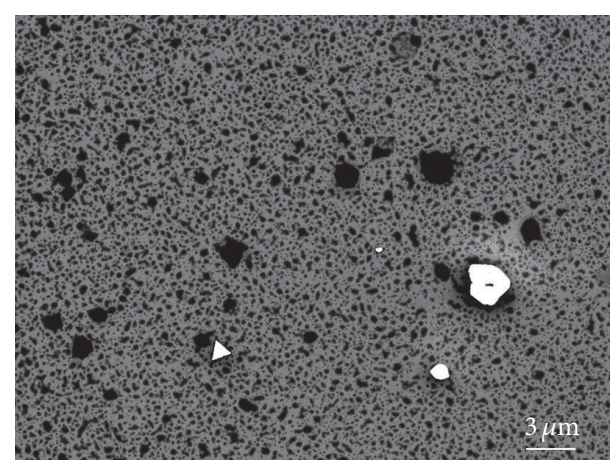

(c)

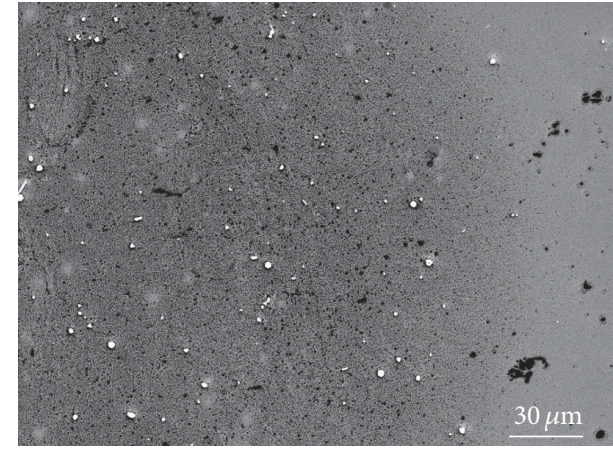

(b)

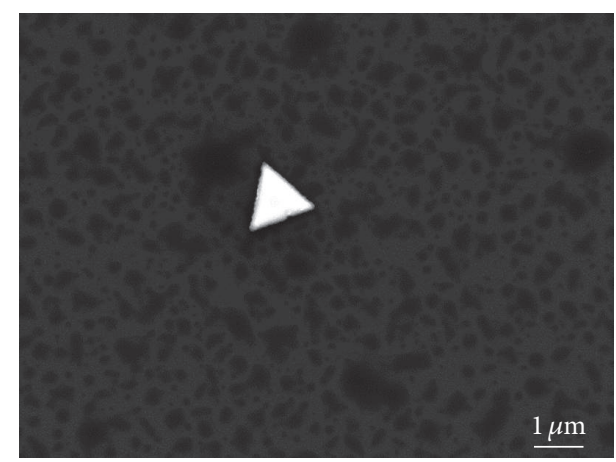

(d)

FIgURE 10: (a) SEM image of a well-patterned $\mathrm{CuSO}_{4}$ solution mixed with 2-propanol (solution \#4) after X-ray irradiation for 5 min. (b) Magnified SEM image of $\mathrm{Cu}$ particles nucleated from the mixed solution under X-ray irradiation. ((c) and (d)) High-resolution SEM images of the synthesized particles.

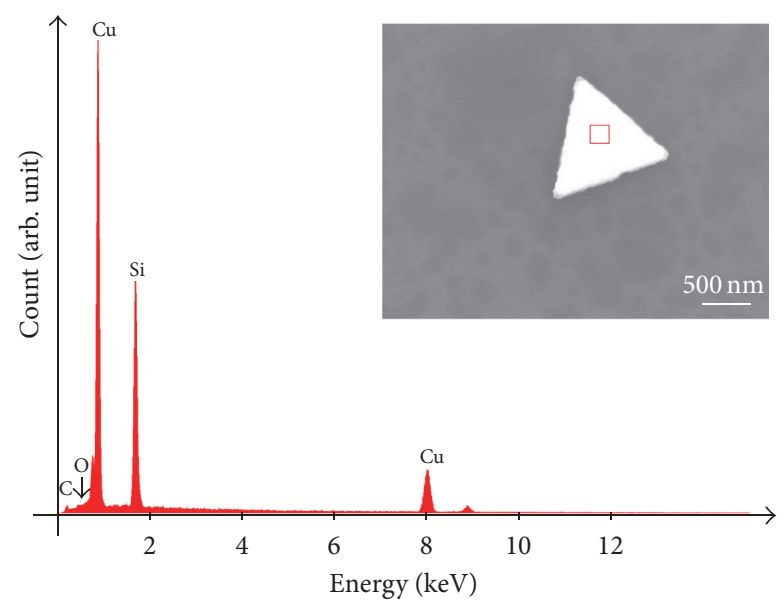

FIGURE 11: EDX spectrum of the red squared area in the synthesized particles observed in Figure 10(d).

synthesized from X-ray radiolysis with (a) methanol, (b) ethanol, (c) 2-propanol, and (d) ethylene glycol are plotted on a function of particle length in Figures 16(a)-16(d), respectively. The synthesized particles under the X-ray irradiation time of 5 min with various additives are similar in size. The result indicates that the irradiation time of $5 \mathrm{~min}$ is long

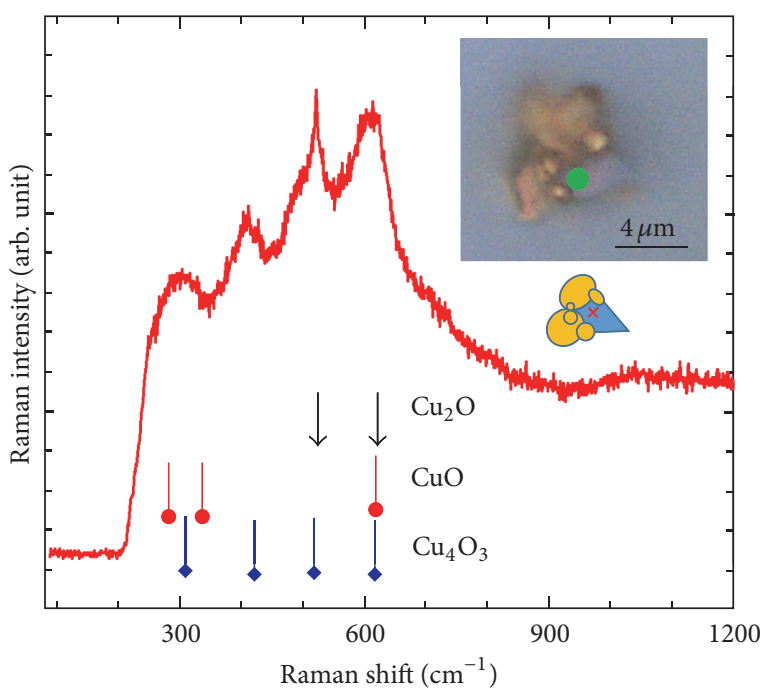

FIGURE 12: Micro-Raman spectra of the measurement position on the synthesized particle aggregate. The inset photograph displays the laser spot position on the aggregate. Indexes were taken from the Raman spectrum patterns: $\mathrm{Cu}_{2} \mathrm{O}, \mathrm{CuO}$, and $\mathrm{Cu}_{4} \mathrm{O}_{3}[38,39]$.

enough to complete the series of nucleation, growth, and aggregation of particles which began and proceeded under 


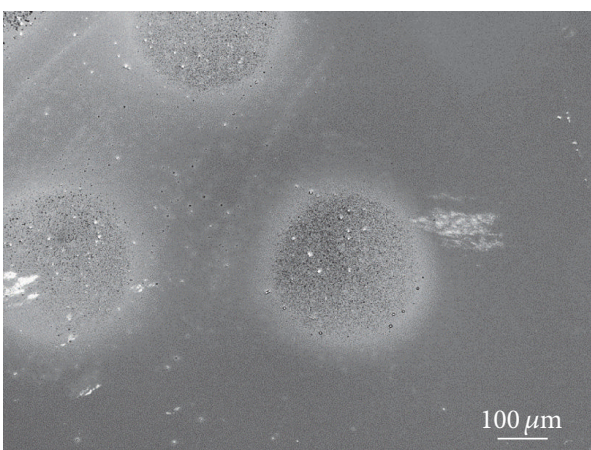

(a)

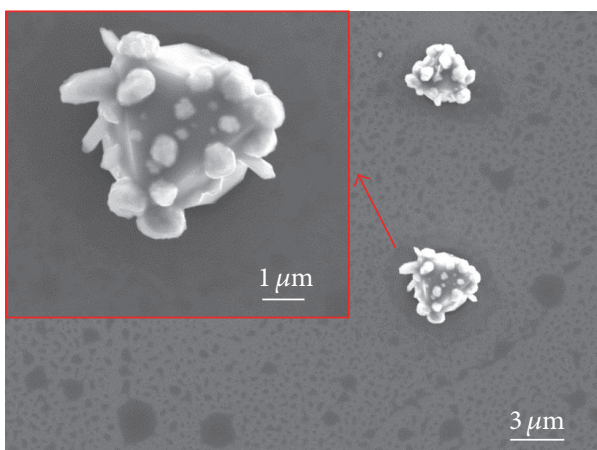

(c)

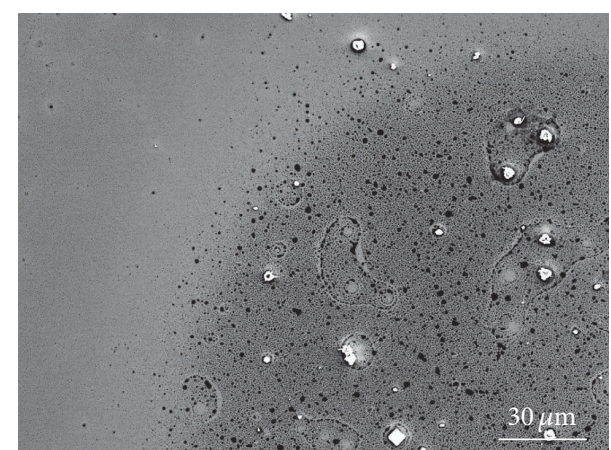

(b)

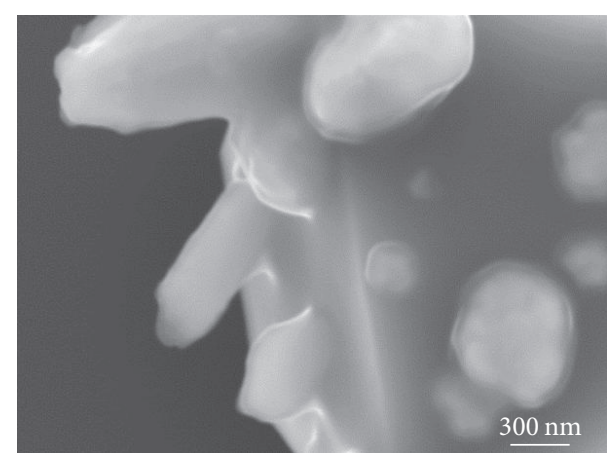

(d)

FIGURE 13: (a) SEM image of a well-patterned $\mathrm{CuSO}_{4}$ solution mixed with ethylene glycol (solution \#5) after X-ray irradiation for 5 min. (b) Magnified SEM image of Cu particles nucleated from the mixed solution under X-ray irradiation. ((c) and (d)) High-resolution SEM images of the synthesized particles.

the competition of LaMer process [66] and DLVO interaction $[67,68]$. Figure 17 shows the dependence of the synthesized particle length on the kinds of alcohol. It seems that the particle length increases with the order: methanol, ethanol, 2-propanol, and ethylene glycol. The trend of synthesis of particles is derived from the radical activity of alcohol, being consistent with the previous studies [65]. On the basis of the high-resolution SEM, TEM, and micro-Raman spectroscopy, we confirmed the synthesis of not only $\mathrm{Cu}$ particles but also higher-order aggregates consisting of cupric oxide and copper particles from liquid solution under X-ray irradiation.

As cupric oxide and cupper particles are receiving considerable interest due to potential uses as anodes lithium ion cells, gas sensors, and p-type semiconductor materials, this X-ray irradiation method can provide a novel additive manufacturing process [69-71] for the devices and systems such as solar cells and plasmonic sensor in $\mu$ TAS. In addition, this study sheds light on developing a three-dimensional printing with both metal and resin as a novel Lithographie Galvanoformung Abformung (LIGA) process [72].

\section{Conclusion}

The present work demonstrates that $\mathrm{Cu} /$ cupric oxide particles can be obtained by irradiating a $\mathrm{CuSO}_{4}$ solution containing alcohol with SR. The synthesized cubic, cuboctahedral, and octahedral NPs aggregate to form higherorder nano/microstructures. High-resolution SEM, TEM, and micro-Raman spectroscopy analyses demonstrated that the core particles consisted of $\mathrm{Cu}_{2} \mathrm{O}, \mathrm{CuO}$, and $\mathrm{Cu}_{4} \mathrm{O}_{3}$, while the particles attached to the core particles were copper. The additive alcohol helps the copper ions to reduce the copper colloids, cupric oxide particles, and $\mathrm{Cu} /$ cupric oxide aggregates. Two potential issues have arisen: (a) the synthetic process including the nucleation and formation of particles from the liquid solution by X-ray irradiation with/without ethanol or other alcohols and (b) the coagulation of the $\mathrm{Cu}$ /cupric oxide particles. These issues are worthy of further investigation.

The direct X-ray irradiation using an SR source can provide an alternative route to explore the novel physical mechanism of liquid/solid interlayer reaction process from the liquid phase. The higher-order nano/microstructure consisting of metallic particles and metal oxides particles offer an opportunity to conveniently and directly induce catalysis and probe surface enhanced Raman scattering. Particularly, cupric oxide particles have attracted much attention for application of gas sensor and solar cell. This one-step direct deposition process can be used in new devices such as "Lab-on-a-chip" and " $\mu$ TAS: micron-Total-Analysis-System" applications for chemical and environmental analyses. In 


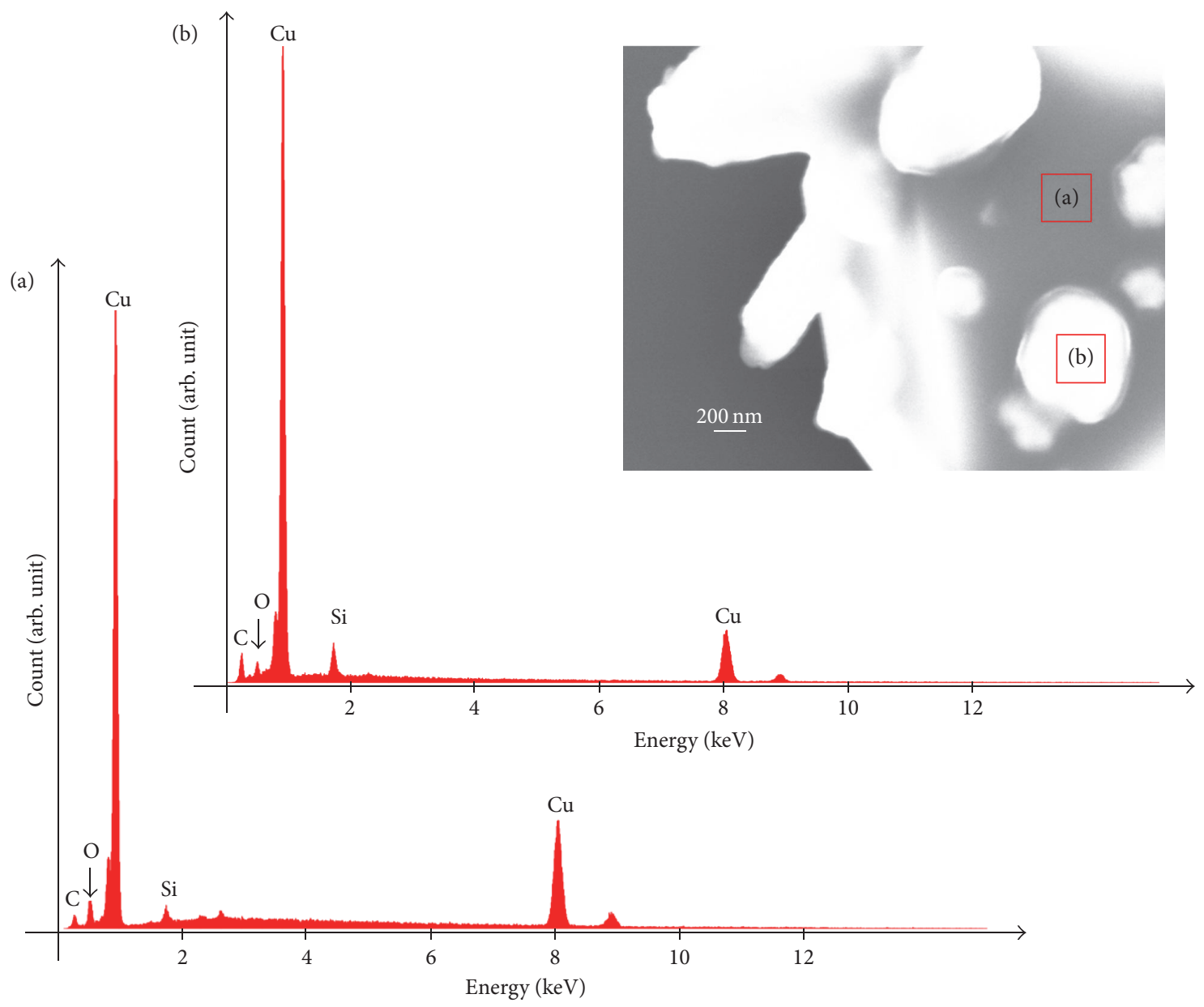

FIGURE 14: EDX spectra of the red squared areas (a) and (b) on the synthesized particles observed in Figure 13(d).

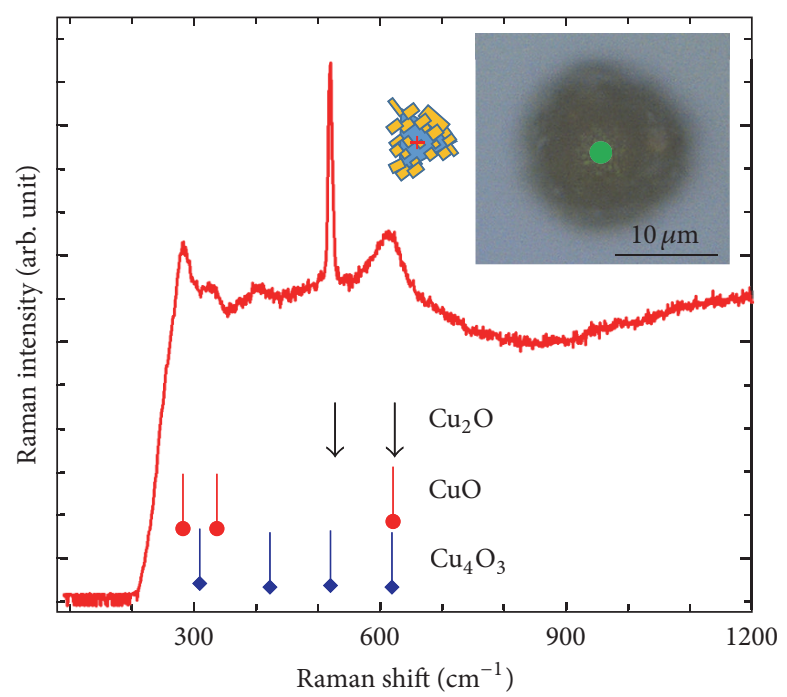

FIGURE 15: Micro-Raman spectrum of the particle aggregate synthesized from $\mathrm{CuSO}_{4}$ solution mixed with ethylene glycol (solution \#5). The inset photographs display the green laser position on the measurement area. Indexes were taken from the following Raman spectrum patterns: $\mathrm{Cu}_{2} \mathrm{O}, \mathrm{CuO}$, and $\mathrm{Cu}_{4} \mathrm{O}_{3}[38,39]$. 


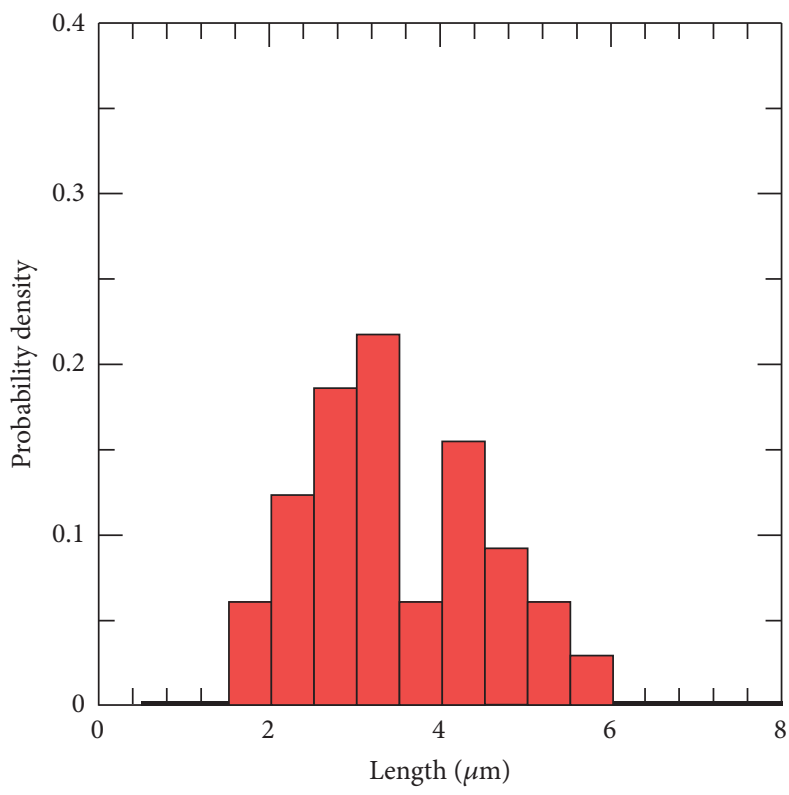

(a)

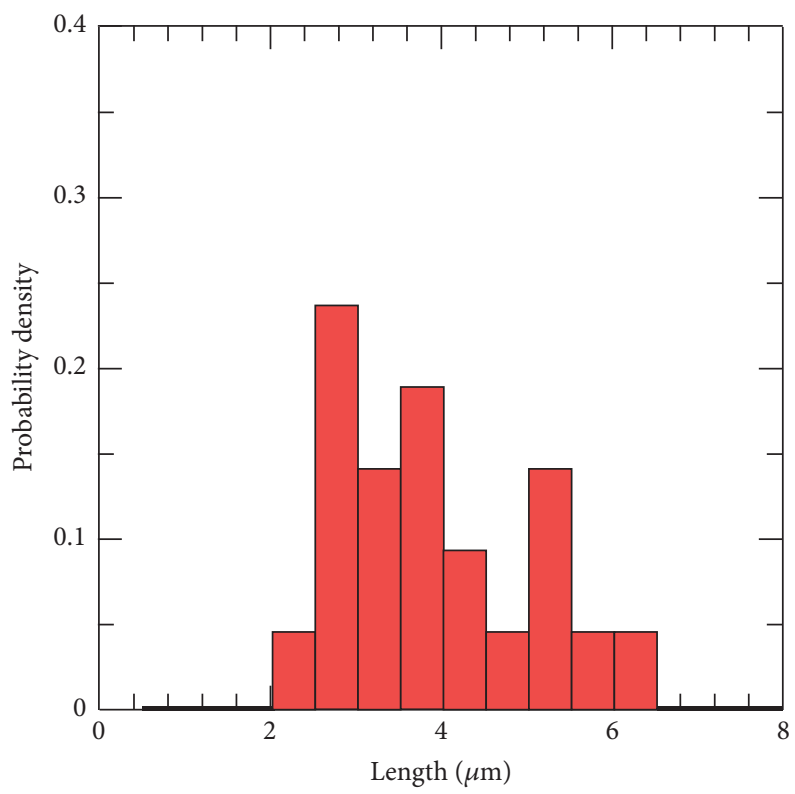

(c)

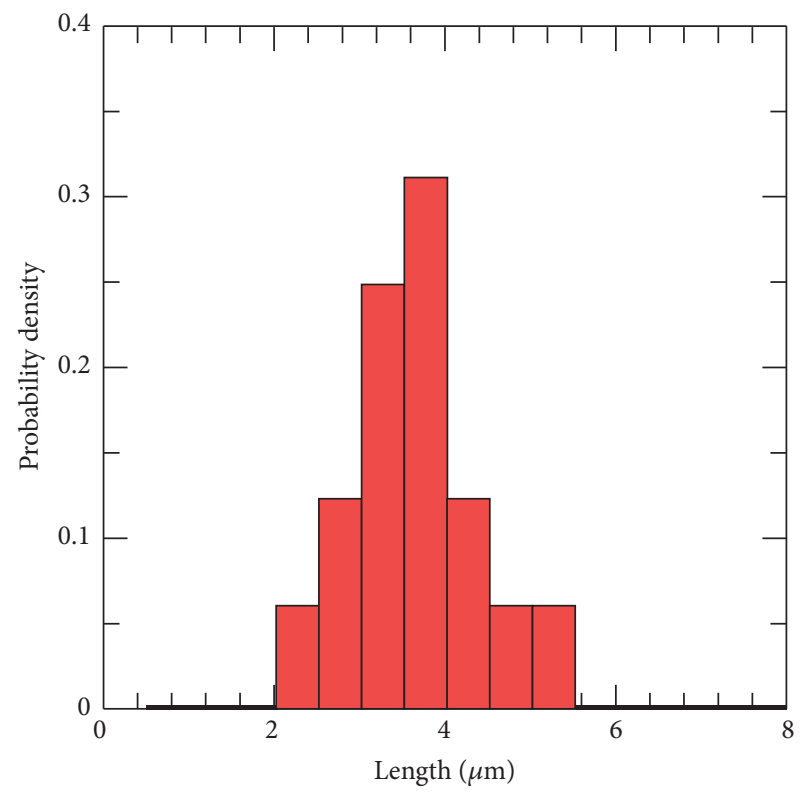

(b)

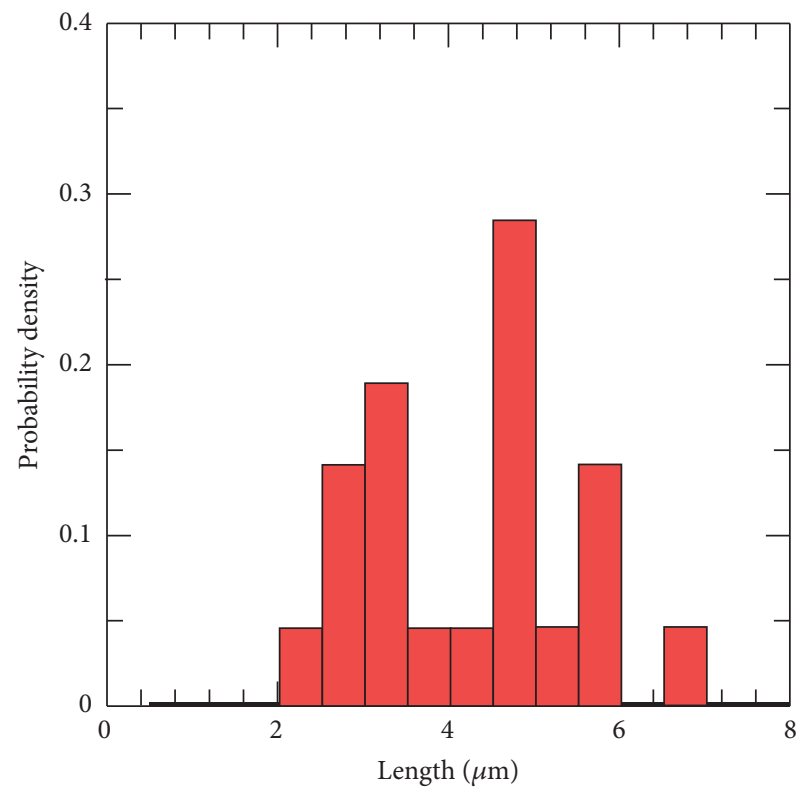

(d)

Figure 16: Probability densities of the particles synthesized $\mathrm{CuSO}_{4}$ mixed with (a) methanol, (b) ethanol, (c) 2-propanol, and (d) ethylene glycol, respectively, revealing the particle length distributions.

addition, the development of this technique combined with the microfluidic chip enables integrating three-dimensional printing which can fabricate micro- or nanoscale structure consisting of metal and resin.

\section{Competing Interests}

The authors declare that they have no competing interests.

\section{Acknowledgments}

The authors are grateful to Dr. Yamaguchi of Hyogo Prefectural Institute for support during SEM and EDX measurement. They thank Dr. Sugimoto of Aichi Prefectural Institute for supporting TEM and EDX measurement. They appreciate Dr. Saiki, Dr. Takizawa of Hyogo Prefectural Institute, and Dr. Ukita of University of Yamanashi for the fruitful discussion. They thank Mitutoyo Association for 


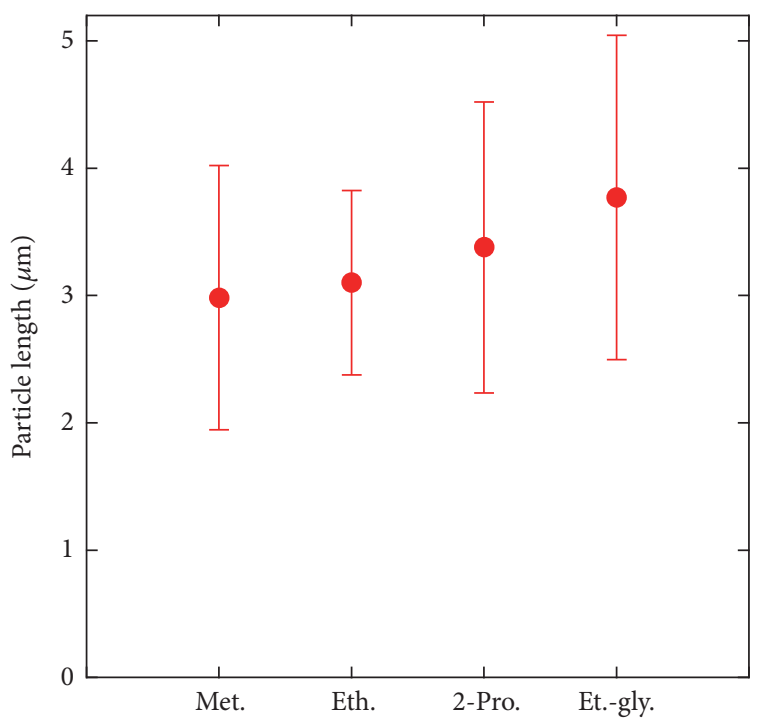

FIGURE 17: Additive alcohol dependence of synthesized particle length. Met., Eth., 2-Pro., and Et.-gly. correspond to methanol, ethanol, 2-propanol, and ethylene glycol, respectively.

Science and Technology. This work is partly supported by Strategic Information and Communications R\&D Promotion Programme. These experiments were conducted at the BL8S1 of Aichi Synchrotron Radiation Center, Aichi Science \& Technology Foundation, Aichi, Japan.

\section{References}

[1] U. Kreibig and M. Vollmer, Optical Properties of Metal Clusters, vol. 25 of Springer Series in Material Science, Springer, 1995.

[2] E. C. Le Ru and P. G. Etchegoin, Principles of Surface-Enhanced Raman Spectroscopy and Related Plasmonic Effects, Elsevier, Amsterdam, The Netherlands, 2009.

[3] X. Lu, M. Rycenga, S. E. Skrabalak, B. Wiley, and Y. Xia, "Chemical synthesis of novel plasmonic nanoparticles," Annual Review of Physical Chemistry, vol. 60, pp. 167-192, 2009.

[4] B. L. Cushing, V. L. Kolesnichenko, and C. J. O’Connor, "Recent advances in the liquid-phase syntheses of inorganic nanoparticles," Chemical Reviews, vol. 104, no. 9, pp. 3893-3946, 2004.

[5] P. Serp and K. Philippot, Eds., Nanomaterials in Catalysis, WILEY-VCH Verlag GmbH \& Co. KGaA, Weinheim, Germany, 2013.

[6] A. Gedanken, "Using sonochemistry for the fabrication of nanomaterials," Ultrasonics Sonochemistry, vol. 11, no. 2, pp. 4755, 2004.

[7] Y. Nagata, Y. Watananabe, S.-I. Fujita, T. Dohmaru, and S. Taniguchi, "Formation of colloidal silver in water by ultrasonic irradiation," Journal of the Chemical Society, Chemical Communications, no. 21, pp. 1620-1622, 1992.

[8] S. A. Yeung, R. Hobson, S. Biggs, and F. Grieser, "Formation of gold sols using ultrasound," Journal of the Chemical Society, Chemical Communications, no. 4, pp. 378-379, 1993.

[9] J. Wagner and J. M. Köhler, "Continuous synthesis of gold nanoparticles in a microreactor," Nano Letters, vol. 5, no. 4, pp. 685-691, 2005.
[10] J. Wagner, T. Kirner, G. Mayer, J. Albert, and J. M. Köhler, "Generation of metal nanoparticles in a microchannel reactor," Chemical Engineering Journal, vol. 101, no. 1-3, pp. 251-260, 2004.

[11] K. S. Suslick, S.-B. Choe, A. A. Cichowlas, and M. W. Grinstaff, "Sonochemical synthesis of amorphous iron," Nature, vol. 353, no. 6343, pp. 414-416, 1991.

[12] W. Tu and H. Liu, "Rapid synthesis of nanoscale colloidal metal clusters by microwave irradiation," Journal of Materials Chemistry, vol. 10, no. 9, pp. 2207-2211, 2000.

[13] T. Yamamoto, Y. Wada, T. Sakata et al., "Microwave-assisted preparation of silver nanoparticles," Chemistry Letters, vol. 33, no. 2, pp. 158-159, 2004.

[14] G. Frens, "Particle size and sol stability in metal colloids," Colloid \& Polymer Science, vol. 250, no. 7, pp. 736-741, 1972.

[15] G. Frens, "Controlled nucleation for the regulation of the particle size in monodisperse gold suspensions," Nature Physical Science, vol. 241, pp. 20-22, 1973.

[16] A. A. Athawale, P. P. Katre, M. Kumar, and M. B. Majumdar, "Synthesis of CTAB-IPA reduced copper nanoparticles," Materials Chemistry and Physics, vol. 91, no. 2-3, pp. 507-512, 2005.

[17] M. Tsuji, M. Hashimoto, Y. Nishizawa, M. Kubokawa, and T. Tsuji, "Microwave-assisted synthesis of metallic nanostructures in solution," Chemistry - A European Journal, vol. 11, no. 2, pp. 440-452, 2005.

[18] A. Takami, H. Kurita, and S. Koda, "Laser-induced size reduction of noble metal particles," The Journal of Physical Chemistry $B$, vol. 103, no. 8, pp. 1226-1232, 1999.

[19] S. Hashimoto, T. Uwada, M. Hagiri, and R. Shiraishi, "Mechanistic aspect of surface modification on glass substrates assisted by single shot pulsed laser-induced fragmentation of gold nanoparticles," Journal of Physical Chemistry C, vol. 115, no. 12, pp. 4986-4993, 2011.

[20] F. Mafuné, J.-Y. Kohno, Y. Takeda, and T. Kondow, "Formation of stable platinum nanoparticles by laser ablation in water," Journal of Physical Chemistry B, vol. 107, no. 18, pp. 4218-4223, 2003.

[21] C. H. Bae, S. H. Nam, and S. M. Park, "Formation of silver nanoparticles by laser ablation of a silver target in $\mathrm{NaCl}$ solution," Applied Surface Science, vol. 197-198, pp. 628-634, 2002.

[22] K. Akamatsu, S. Ikeda, H. Nawafune, and H. Yanagimoto, "Direct patterning of copper on polyimide using ion exchangeable surface templates generated by site-selective surface modification," Journal of the American Chemical Society, vol. 126, no. 35, pp. 10822-10823, 2004.

[23] K. Akamatsu, M. Fujii, T. Tsuruoka, S.-I. Nakano, T. Murashima, and H. Nawafune, "Mechanistic study on microstructural tuning of metal nanoparticle/polymer composite thin layers: hydrogenation and decomposition of polyimide matrices catalyzed by embedded nickel nanoparticles," Journal of Physical Chemistry C, vol. 116, no. 33, pp. 17947-17954, 2012.

[24] F. Fievet, J. P. Lagier, B. Blin, B. Beaudoin, and M. Figlarz, "Homogeneous and heterogeneous nucleations in the polyol process for the preparation of micron and submicron size metal particles," Solid State Ionics, vol. 32-33, part 1, pp. 198-205, 1989.

[25] L. K. Kurihara, G. M. Chow, and P. E. Schoen, "Nanocrystalline metallic powders and films produced by the polyol method," Nanostructured Materials, vol. 5, no. 6, pp. 607-613, 1995.

[26] B. Wiley, T. Herricks, Y. Sun, and Y. Xia, "Polyol synthesis of silver nanoparticles: use of chloride and oxygen to promote the formation of single-crystal, truncated cubes and tetrahedrons," Nano Letters, vol. 4, no. 9, pp. 1733-1739, 2004. 
[27] L. Kvítek, A. Panáček, J. Soukupová et al., "Effect of surfactants and polymers on stability and antibacterial activity of silver nanoparticles (NPs)," Journal of Physical Chemistry C, vol. 112, no. 15, pp. 5825-5834, 2008.

[28] R. Hara, T. Fukuoka, R. Takahashi, Y. Utsumi, and A. Yamaguchi, "Surface-enhanced Raman spectroscopy using a coffeering-type three-dimensional silver nanostructure," RSC Advances, vol. 5, no. 2, pp. 1378-1384, 2015.

[29] Q. Ma, N. Moldovan, D. C. Mancini, and R. A. Rosenberg, "Synchrotron-radiation-induced, selective-area deposition of gold on polyimide from solution," Applied Physics Letters, vol. 76, no. 15, p. 2014, 2000.

[30] P. H. Borse, J. M. Yi, J. H. Je, W. L. Tsai, and Y. Hwu, " $p H$ dependence of synchrotron x-ray induced electroless nickel deposition," Journal of Applied Physics, vol. 95, no. 3, pp. 11661170, 2004.

[31] P. H. Borse, J. M. Yi, J. H. Je et al., "Formation of magnetic Ni nanoparticles in x-ray irradiated electroless solution," Nanotechnology, vol. 15, no. 6, pp. S389-S392, 2004.

[32] Y.-C. Yang, C.-H. Wang, Y.-K. Hwu, and J.-H. Je, "Synchrotron $\mathrm{X}$-ray synthesis of colloidal gold particles for drug delivery," Materials Chemistry and Physics, vol. 100, no. 1, pp. 72-76, 2006.

[33] C.-L. Wang, B.-J. Hsao, S.-F. Lai et al., "One-pot synthesis of AuPt alloyed nanoparticles by intense x-ray irradiation," Nanotechnology, vol. 22, no. 6, Article ID 065605, 2011.

[34] F. Karadas, G. Ertas, E. Ozkaraoglu, and S. Suzer, "X-rayinduced production of gold nanoparticles on a $\mathrm{SiO}_{2} / \mathrm{Si}$ system and in a poly(methyl methacrylate) matrix," Langmuir, vol. 21, no. 1, pp. 437-442, 2005.

[35] H. J. Lee, J. H. Je, Y. Hwu, and W. Tsai, "Synchrotron Xray induced solution precipitation of nanoparticles," Nuclear Instruments and Methods in Physics Research Section B: Beam Interactions with Materials and Atoms, vol. 199, pp. 342-347, 2003.

[36] A. Yamaguchi, T. Matsumoto, I. Okada, I. Sakurai, and Y. Utsumi, "Surface-enhanced Raman scattering active gold nanostructure fabricated by photochemical reaction of synchrotron radiation," Materials Chemistry and Physics, vol. 160, pp. 205-211, 2015.

[37] S. K. Ghosh and T. Pal, "Interparticle coupling effect on the surface plasmon resonance of gold nanoparticles: from theory to applications," Chemical Reviews, vol. 107, no. 11, pp. 47974862, 2007.

[38] D. P. Volanti, D. Keyson, L. S. Cavalcante et al., "Synthesis and characterization of $\mathrm{CuO}$ flower-nanostructure processing by a domestic hydrothermal microwave," Journal of Alloys and Compounds, vol. 459, no. 1-2, pp. 537-542, 2008.

[39] L. Debbichi, M. C. Marco De Lucas, J. F. Pierson, and P. Krüger, "Vibrational properties of $\mathrm{CuO}$ and $\mathrm{Cu}_{4} \mathrm{O}_{3}$ from first-principles calculations, and raman and infrared spectroscopy," Journal of Physical Chemistry C, vol. 116, no. 18, pp. 10232-10237, 2012.

[40] P. Poizot, S. Laruelle, S. Grugeon, L. Dupont, and J.-M. Tarascon, "Nano-sized transition-metal oxides as negative-electrode materials for lithium-ion batteries," Nature, vol. 407, no. 6803, pp. 496-499, 2000.

[41] J. C. Park, A. Y. Kim, J. Y. Kim, S. Park, K. H. Park, and H. Song, "ZnO-CuO core-branch nanocatalysts for ultrasound-assisted azide-alkyne cycloaddition reactions," Chemical Communications, vol. 48, no. 68, pp. 8484-8486, 2012.

[42] A. Henglein, "Formation and absorption spectrum of copper nanoparticles from the radiolytic reduction of $\mathrm{Cu}(\mathrm{CN})$," The
Journal of Physical Chemistry B, vol. 104, no. 6, pp. 1206-1211, 2000.

[43] J. Long, J. Dong, X. Wang et al., "Photochemical synthesis of submicron- and nano-scale $\mathrm{Cu}_{2} \mathrm{O}$ particles," Journal of Colloid and Interface Science, vol. 333, no. 2, pp. 791-799, 2009.

[44] M. A. Dar, Q. Ahsanulhaq, Y. S. Kim, J. M. Sohn, W. B. Kim, and H. S. Shin, "Versatile synthesis of rectangular shaped nanobatlike $\mathrm{CuO}$ nanostructures by hydrothermal method; structural properties and growth mechanism," Applied Surface Science, vol. 255, no. 12, pp. 6279-6284, 2009.

[45] M.-S. Yeh, Y.-S. Yang, Y.-P. Lee, H.-F. Lee, Y.-H. Yeh, and C.-S. Yeh, "Formation and characteristics of $\mathrm{Cu}$ colloids from $\mathrm{CuO}$ powder by laser irradiation in 2-propanol," Journal of Physical Chemistry B, vol. 103, no. 33, pp. 6851-6857, 1999.

[46] A. Radi, D. Pradhan, Y. Sohn, and K. T. Leung, "Nanoscale shape and size control of cubic, cuboctahedral, and octahedral $\mathrm{Cu}-$ $\mathrm{Cu}_{2} \mathrm{O}$ core-shell nanoparticles on $\mathrm{Si}(100)$ by one-step, templateless, capping-agent-free electrodeposition," ACS Nano, vol. 4, no. 3, pp. 1553-1560, 2010.

[47] M. Izaki, T. Shinagawa, K.-T. Mizuno, Y. Ida, M. Inaba, and A. Tasaka, "Electrochemically constructed $\mathrm{p}-\mathrm{Cu}_{2} \mathrm{O} / \mathrm{n}-\mathrm{ZnO}$ heterojunction diode for photovoltaic device," Journal of Physics D: Applied Physics, vol. 40, no. 11, p. 3326, 2007.

[48] T. H. Fleisch and G. J. Mains, "Reduction of copper oxides by UV radiation and atomic hydrogen studied by XPS," Applications of Surface Science, vol. 10, no. 1, pp. 51-62, 1982.

[49] J. Tamaki, K. Shimanoe, Y. Yamada, Y. Yamamoto, N. Miura, and N. Yamazoe, "Dilute hydrogen sulfide sensing properties of $\mathrm{CuO}-\mathrm{SnO}_{2}$ thin film prepared by low-pressure evaporation method," Sensors and Actuators, B: Chemical, vol. 49, no. 1-2, pp. 121-125, 1998.

[50] W. Shao, G. Pattanaik, and G. Zangari, "Electrochemical nucleation and growth of copper from acidic sulfate electrolytes on n-Si ( 001 )," Journal of the Electrochemical Society, vol. 154, no. 7, pp. D339-D345, 2007.

[51] J. Zhang, J. Liu, Q. Peng, X. Wang, and Y. Li, "Nearly monodisperse $\mathrm{Cu}_{2} \mathrm{O}$ and $\mathrm{CuO}$ nanospheres: preparation and applications for sensitive gas sensors," Chemistry of Materials, vol. 18, no. 4, pp. 867-871, 2006.

[52] R. T. Clay and R. E. Cohen, "Synthesis of $\mathrm{Cu}$ and $\mathrm{CuO}$ nanoclusters within microphase-separated diblock copolymers," New Journal of Chemistry, vol. 22, no. 7, pp. 745-748, 1998.

[53] I. Lisiecki and M. P. Pileni, "Synthesis of copper metallic clusters using reverse micelles as microreactors," Journal of the American Chemical Society, vol. 115, no. 10, pp. 3887-3896, 1993.

[54] M. A. Brookshier, C. C. Chusuei, and D. W. Goodman, "Control of $\mathrm{CuO}$ particle size on $\mathrm{SiO}_{2}$ by spin coating," Langmuir, vol. 15, no. 6, pp. 2043-2046, 1999.

[55] H. Oyanagi, Y. Orimoto, K. Hayakawa et al., "Nanoclusters synthesized by synchrotron radiolysis in concert with wet chemistry," Scientific Reports, vol. 4, article 7199, 2014.

[56] A. Yamaguchi, I. Okada, T. Fukuoka, I. Sakurai, and Y. Utsumi, "Synthesis of metallic nanoparticles through X-ray radiolysis using synchrotron radiation," Japanese Journal of Applied Physics, vol. 55, no. 5, Article ID 055502, 2016.

[57] T. Ishihara, M. Higuchi, T. Takagi, M. Ito, H. Nishiguchi, and Y. Takita, "Preparation of $\mathrm{CuO}$ thin films on porous $\mathrm{BaTiO}_{3}$ by self-assembled multibilayer film formation and application as a $\mathrm{CO}_{2}$ sensor," Journal of Materials Chemistry, vol. 8, no. 9, pp. 2037-2042, 1998. 
[58] J. Luo, L. Steier, M. -K. Son, M. Schreier, M. T. Mayer, and M. Grätzel, " $\mathrm{Cu}_{2} \mathrm{O}$ nanowire photocathodes for efficient and durable solar water splitting," Nano Letters, vol. 16, no. 3, pp. 18481857, 2016.

[59] J. Weiss, "Radiochemistry of aqueous solutions," Nature, vol. 153, pp. 748-750, 1944.

[60] J. Weiss, "Biological action of radiations," Nature, vol. 157, p. 584, 1946.

[61] N. Miller, "Quantitative studies of radiation-induced reactions in aqueous solution. I. Oxidation of ferrous sulfate by $\mathrm{X}-$ and $\gamma$-radiation," The Journal of Chemical Physics, vol. 18, no. 1, p. 79, 1950.

[62] A. H. Samuel and J. L. Magee, "Theory of radiation chemistry. II. Track effects in radiolysis of water," The Journal of Chemical Physics, vol. 21, no. 6, pp. 1080-1087, 1953.

[63] R. H. Johnsen, N. T. Barker, and M. Burgin, "Studies on iodine as a scavenger in irradiated hydrocarbons and hydrocarbonalcohol solutions," The Journal of Physical Chemistry, vol. 73, no. 10, pp. 3204-3208, 1969.

[64] N. Getoff, "Radiation-induced degradation of water pollutants-state of the art," Radiation Physics and Chemistry, vol. 47, no. 4, pp. 581-593, 1996.

[65] G. V. Buxton, C. L. Greenstock, W. P. Helman, and A. B. Ross, "Critical Review of rate constants for reactions of hydrated electrons, hydrogen atoms and hydroxyl radicals $\left(\cdot \mathrm{OH} / \cdot \mathrm{O}^{-}\right.$in Aqueous Solution," Journal of Physical and Chemical Reference Data, vol. 17, no. 2, p. 513, 1998.

[66] V. K. LaMer and R. H. Dinegar, "Theory, production and mechanism of formation of monodispersed hydrosols," Journal of the American Chemical Society, vol. 72, no. 11, pp. 4847-4854, 1950.

[67] R. Hogg, T. W. Healy, and D. W. Fuerstenau, "Mutual coagulation of colloidal dispersions," Transactions of the Faraday Society, vol. 62, pp. 1638-1651, 1966.

[68] J. N. Israelacvili, Intermolecular and Surface Forces, Academic Press, London, UK, 3rd edition, 2011.

[69] W. E. Frazier, "Metal additive manufacturing: a review," Journal of Materials Engineering and Performance, vol. 23, no. 6, pp. 1917-1928, 2014.

[70] K. V. Wong and A. Hernandez, "A review of additive manufacturing," ISRN Mechanical Engineering, vol. 2012, Article ID 208760, 10 pages, 2012.

[71] L. Jonušauskas, M. Lau, P. Gruber et al., "Plasmon assisted 3D microstructuring of gold nanoparticle-doped polymers," Nanotechnology, vol. 27, no. 15, 2016.

[72] V. Saile, U. Wallradbe, O. Tabata, and J. G. Korvink, Advanced Micro and Nanosystems, Volume 7: LIGA and Its Applications, Wiley-VCH, Weinheim, Germany, 2009. 

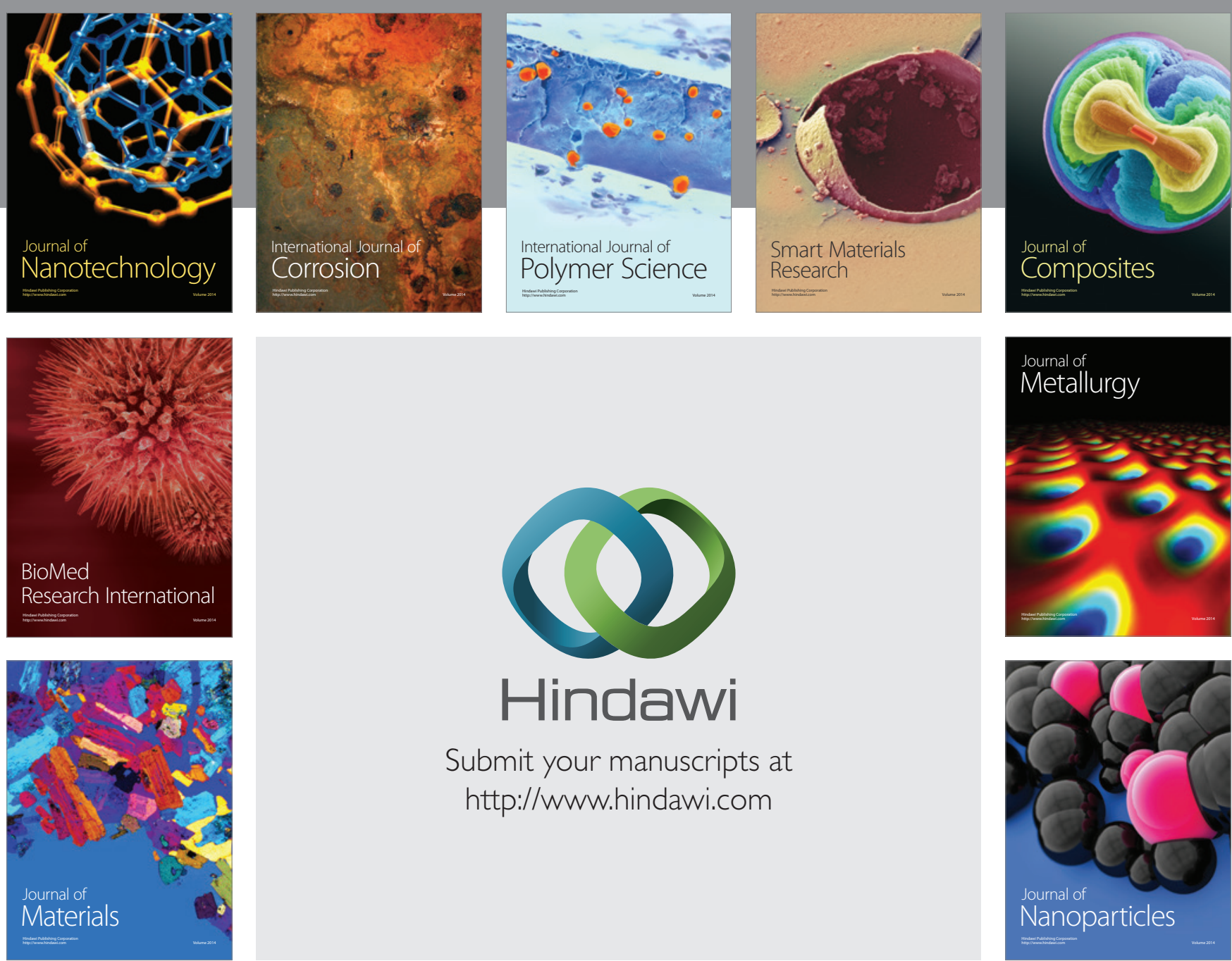

\section{Hindawi}

Submit your manuscripts at

http://www.hindawi.com

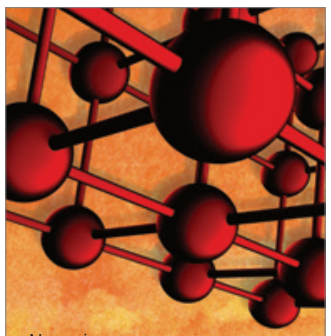

Materials Science and Engineering
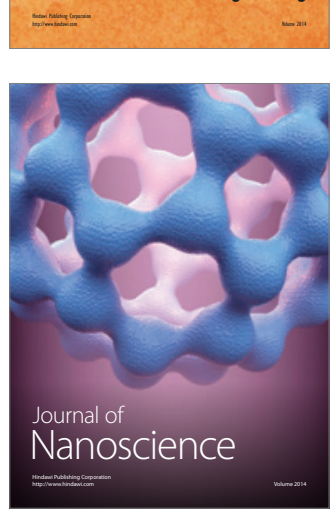
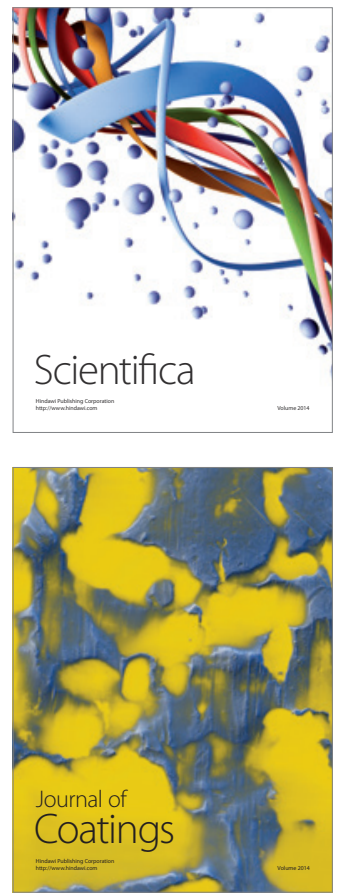
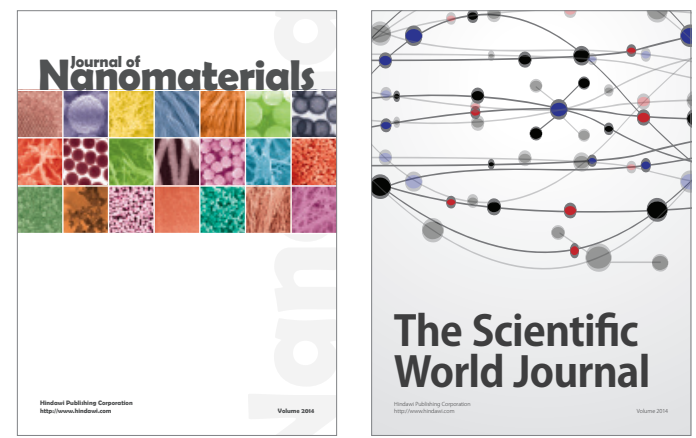

The Scientific World Journal
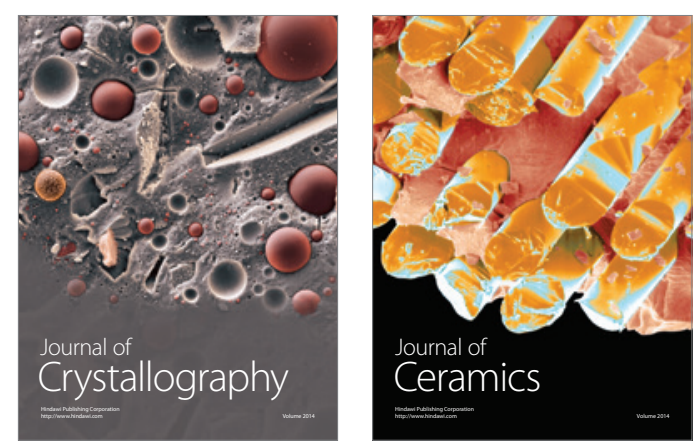
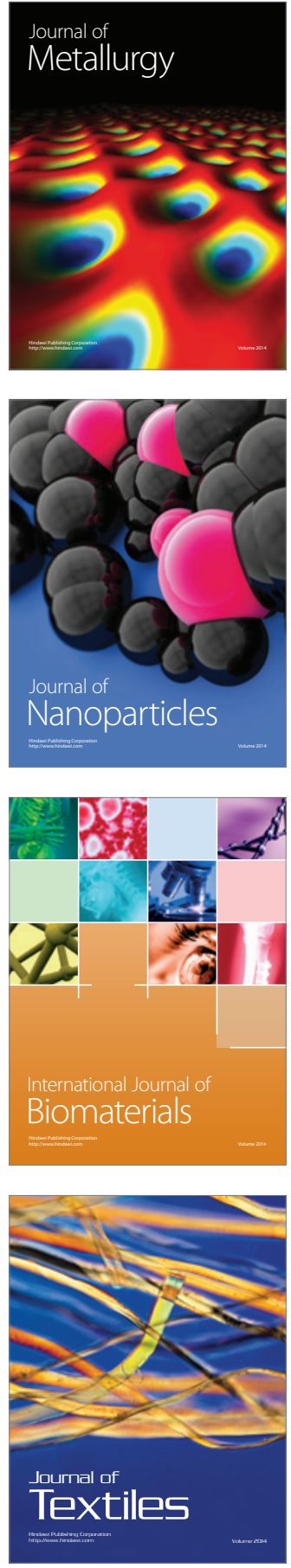